\title{
Effect of viral hemorrhagic septicemia virus on Pacific herring in Prince William Sound, Alaska, from 1989 to 2005
}

\author{
Ralph A. Elston ${ }^{1, *}$, Theodore R. Meyers ${ }^{2}$ \\ ${ }^{1}$ AquaTechnics Inc., PO Box 687, Carlsborg, Washington 98324, USA \\ ${ }^{2}$ Alaska Department of Fish and Game, Commercial Fisheries Division, PO Box 25526, Juneau, Alaska 99802-5526, USA
}

\begin{abstract}
We critically review the role of viral hemorrhagic septicemia virus (VHSV) in the 1992-1993 collapse of the Prince William Sound (PWS) herring fishery. VHSV was detected in samples of moribund Pacific herring from PWS in spring 1993 when about $63 \%$ of the expected fish failed to appear. A low prevalence and severity of VHSV were observed in adult pre-spawning PWS herring in most of the years from 1994 to 2002. The North American strain of VHSV became established about $500 \mathrm{yr}$ ago in many northeast Pacific marine fish species, including herring. In Alaska, the typical annual prevalence of VHSV in pre-spawning herring ranges from 0 to $17 \%$. New threshold analysis of a 9 yr study indicates that only about half of the virus-infected adult fish in PWS were clinically affected; ulcers formerly attributed to VHS have been overestimated by a factor of about 3 . We conclude that VHSV was not a primary causative factor in the PWS herring population collapse or in its failure to recover. Because older age classes of herring were not disproportionately missing in 1993, the protozoan Ichthyophonus hoferi was also not a likely cause of losses. The 'Exxon Valdez' oil spill occurred in PWS, Alaska, USA, in 1989. Evidence for interaction of oil and VHSV expression is also evaluated. A study exposing herring to varying concentrations of weathered crude oil showed increasing prevalences of VHSV correlated with oil concentration; however, repeated experiments with juvenile and adult fish failed to corroborate these results or link oil to VHSV infection in herring.
\end{abstract}

KEY WORDS: Pacific herring · Clupea pallasi · VHSV · 'Exxon Valdez' oil spill Resale or republication not permitted without written consent of the publisher

\section{INTRODUCTION}

The 'Exxon Valdez' oil spill (EVOS) occurred on 24 March 1989 in Prince William Sound (PWS), Alaska. Subsequent Pacific herring Clupea pallasi harvests in PWS were at or near record levels from 1990 to 1992, but the fishery collapsed during the winter of 1992-1993 and has been commercially fished for only 2 yr since 1992. Controversy has surrounded determination of the cause for the collapse and the failure of the fishery to recover. Hypotheses regarding causative factors in the herring population collapse and failure to recover have been debated since 1993, including the possible role of herring infectious diseases and the potential effect of oil from the EVOS on herring disease susceptibility.

In this review, we conduct a comprehensive examination of known information about one of the principal diseases of Pacific herring in PWS, viral hemorrhagic septicemia (VHS), and its impact on the herring population. The role of VHS virus (VHSV) in the herring collapse has received considerable attention because the virus was first detected in herring soon after the collapse occurred (Meyers et al. 1994). Subsequent studies (Traxler et al. 1994, 1999, Meyers et al. 1999, Hedrick et al. 2003) have shown the virus to be wide- 
spread in Pacific populations of herring and other forage species. We present for the first time an alternative and more substantive interpretation of virological data for PWS herring examined from 1994 to 2002. Our objectives were to establish the role this disease may have had in the collapse of the population in 1992-1993 and in its subsequent failure to recover, and to assess evidence for exacerbating effects of oil exposure on this disease. Key information gaps have been identified, as well as the most probable hypotheses regarding the relationship of VHSV and the EVOS to the PWS herring population decline. We also identified hypotheses for which there is no support or scientific basis. Several authors have used virological and other disease-related data to model disease effects on the herring population (Quinn et al. 2001, Marty et al. $2003,2004)$. We, therefore, have provided in this review a re-evaluation and a more probable and scientifically conservative alternative interpretation of virological data from PWS herring that should be used for future modeling efforts incorporating infectious disease effects. These objectives were undertaken from the broadest perspective possible, as evidenced by the differing affiliation and support of the 2 authors. We believe this review is urgently needed to provide a clearer and more logical interpretation of the data than has been done to date.

Infection by the protozoan Ichthyophonus hoferi may be an emerging disease in a variety of Pacific marine and anadromous fishes, including herring. The pathogen severely affects fish (Kocan et al. 2006) progressively as they age (Hershberger et al. 1999), and the observed prevalence in PWS particularly after 2002 suggests it may be limiting survival of herring $5 \mathrm{yr}$ and older (Marty et al. 2004). However, the 1993 PWS herring population collapse affected all adult age classes nearly equally, rather than selectively affecting older fish (Marty et al. 2003, 2004). Also, based on available histological data, there was no marked reduction in prevalence of ichthyophoniasis following the collapse, which would be indicative of an $I$. hoferi-related mortality. These findings indicated that $I$. hoferi cannot be assigned a primary role in the 1993 collapse. Thus, we have excluded consideration of this pathogen from this review of disease factors affecting the 1993 collapse and recovery failure.

\section{VIRAL HEMORRHAGIC SEPTICEMIA}

\section{Host range and evolution of North American VHSV}

The European strain of VHSV has been known for many years, due in part to its severe impact on rainbow trout farms in Europe. More recently, the North Amer- ican strain of VHSV (Type IVa), which is far less pathogenic for salmonids, was discovered in adult Pacific Northwest anadromous salmon in 1988 (Hopper 1989, Winton et al. 1991). The subsequent discovery that VHSV was indigenous to Pacific herring and other forage species provided an explanation (Meyers et al. 1994) for the earlier isolations of the virus from asymptomatic adult Coho Oncorhynchus kisutch and Chinook O. tshawytscha salmon returning to Washington waters (Brunson et al. 1989, Hopper 1989, Eaton \& Hulett 1990, Stewart et al. 1990, Winton et al. 1991).

Early genetic analysis indicated that the North American strain had a nearly unique 28-nucleotide sequence following the open reading frame of the Ngene mRNA that distinguished the virus from the European strain (Batts et al. 1993). Further molecular analysis of the N-gene fragment indicated the North American VHSV was almost exclusively genotype IV among 3 other genotypes worldwide (Snow et al. 1999). Exceptions included genotype IV Japanese and Korean isolates and genotype III isolates from the Flemish Cap close to Newfoundland (reviewed by Skall et al. 2005, López-Vázquez et al. 2006). Additional analysis of the estimated nucleotide substitution rate of the entire $G$ gene indicated that the North American strain of VHSV (Type IVa) probably diverged from the European marine strain about $500 \mathrm{yr}$ ago, suggesting a long history in the marine environment and explaining its wide host and geographic distribution among fishes of the Northeast Pacific (Basurco et al. 1995, Einer-Jensen et al. 2004). In addition to the genetic evidence for the lengthy presence of VHSV in the northeast Pacific, prior epizootic mortality of herring has exhibited similarities to what is now known as VHS disease (Marty et al. 1998), although no confirmatory evidence is available to establish VHSV as the causative agent.

Species of marine fish known to have detectable levels of North American VHSV with varying susceptibilities include steelhead Oncorhynchus mykiss, Pacific cod Gadus macrocephalus, Chinook O. tshawytscha and Coho salmon O. kisutch, Pacific herring Clupea pallasi (Winton et al. 1991, Meyers et al. 1992, Traxler \& Kieser 1994, Meyers \& Winton 1995), Pacific sand lance Ammodytes hexapterus, English sole Parophrys vetulus, shiner perch Cymatogaster aggregata (Traxler et al. 1995, Kent et al. 1998, Hershberger et al. 1999), pollock Theragra chalcogramma, Pacific hake Merluccius productus, Pacific tomcod Microgadus proximus (Meyers et al. 1999), eulachon Thaleichthys pacificus, surf smelt Hypomesus pretiosus pretiosus, Pacific mackerel Scomber japonicus, sablefish Anoplopoma fimbria, and Pacific sardines Sardinops sagax (Traxler et al. 1999, Hedrick et al. 2003). The virus has also been isolated from asymptomatic three-spined stickle- 
backs Gasterosteus aculeatus captured near marine netpen salmon farms (Kent et al. 1998).

Most recently, North American VHSV (Type IVa) has been detected from asymptomatic Atlantic herring Clupea harengus on the east coast of the USA (MacLean 2006) and a new sublineage (Type IVb) has been identified in association with mortality in mummichogs Fundulus heteroclitus, sea-run brown trout Salmo trutta, stickleback and striped bass Morone saxatilis in New Brunswick and Nova Scotia, Canada (Gagne et al. 2007). The Type IVb virus has also been associated with epizootic mortality in freshwater fish, including drum Aplodinotus grunniens from Lake Ontario (Lumsden et al. 2007), muskellunge Esox masquinongy from Lake St. Clair, Michigan (Elsayed et al. 2006), and round goby Neogobius melanostomus in Lake Ontario and the St. Lawrence River (Groocock et al. 2007). This new virus has also been reported to cause significant mortality in yellow perch Perca flavescens, emerald shiners Notropis atherinoides, gizzard shad Dorosoma cepedianum, burbot Lota lota, and smallmouth bass Micropterus dolomieui (Winton et al. 2007). The Type IVb strain of VHSV has a broad host range, having been detected in more than 28 species of freshwater fish in the Great Lakes, and inland lakes in New York, Michigan, and Wisconsin (Winton et al. 2007, 2008).

\section{Epizootiology and pathogenesis of VHS in Pacific herring}

Seasonality and age

In PWS, VHSV typically has been isolated from adult pre-spawning herring during spring spawning aggregations. During this period, outbreaks of VHS disease have been observed, likely caused by increased stress from sexual maturation, lower body condition, and overall lower resistance to disease (Meyers \& Winton 1995). However, 9 yr of sampling for VHSV in PWS during the fall, including October 1993 (Meyers \& Winton 1995), failed to isolate the virus from adult fish, probably as a result of better body condition and improved immunity during the summer (Marty et al. 2004). In other geographic areas, such as along the coast of British Columbia, VHSV has been isolated from adult Pacific herring during September and October (Traxler \& Kieser 1994). The isolation of low levels of VHSV in a relatively small proportion (typically between 0 and $17 \%$ of fish) of clinically healthy spring spawning fish is not unusual (Hershberger et al. 1999, Marty et al. 2004) and is a recurrent feature of Pacific herring biology in PWS and around the North Pacific (Meyers \& Winton 1995, Kocan et al. 2001, Hershberger et al. 2006).
VHS is generally considered a disease of younger herring. The causative virus has been isolated from age-0+ fish in the Puget Sound, Washington, region between early July and late September (Kocan et al. 2001). These fish either expressed the virus shortly after transfer into laboratory holding tanks or, in a single fish, the virus was isolated directly after capture. Kocan et al. (2001) found that a proportion of groups of wild-caught age-0+ herring were either highly susceptible to the disease when brought into captivity or were strongly refractory to infection, presumably from acquired immunity to the virus through resolution of a prior natural infection.

Hershberger et al. (1999) studied VHSV infection in the spawn-on-kelp (SOK) herring pound fishery in PWS and clearly showed that the prevalence of virus and clinical disease were highest in the very youngest captive fish and diminished steadily with fish age. In 1998, Hershberger et al. (1999) found an average prevalence of VHSV of about $60 \%$ in 1- and 2-yr-old fish that declined by year class to about $15 \%$ in 7 - to 10-yr-old fish (Fig. 1). Furthermore, virus prevalence peak values were higher in the second year of the study $(60.0$ to $85.5 \%)$ compared to the first year $(12.5$ to $25 \%$ ). The higher prevalence values in the second year were attributed to a greater proportion of the more susceptible younger age class fish. These prevalence values represent expression of the virus induced by the stress of confinement ( 0.9 to $>18$ metric tons herring per containment pound) and transmission to other captive uninfected fish, as shown by an initial peak followed by a second peak of infection.

Transmission and mortality

The VHSV infection cycle in Pacific herring runs its course in less than 1 mo from first detection, resulting in either mortality or resolution and survival of the host. Survival results in the development of a strong acquired immunity (Hershberger et al. 1999). The most typical finding by Kocan et al. (2001) was that captured wild age-0+ herring in Puget Sound did not have VHSV as detected by culture, but rapidly broke with the disease: 4 groups of fish exhibited mortality rates from 0 to about $56 \%$, with 2 intermediate groups showing cumulative mortality of about 14 and $18 \%$. VHSV was isolated from moribund and dead fish at tissue concentrations of from $7 \times 10^{4}$ plaque forming units (pfu) $\mathrm{g}^{-1}$ to $1 \times 10^{8} \mathrm{pfu} \mathrm{g}^{-1}$. The prevalence and intensity of infection peaked after $7 \mathrm{~d}$ in captivity, and by $30 \mathrm{~d}$ post-capture, the virus could not be detected in surviving fish. Kocan et al. (2001) attributed the infection of herring in the laboratory to the shedding of the virus by a small percentage of fish in the transport 


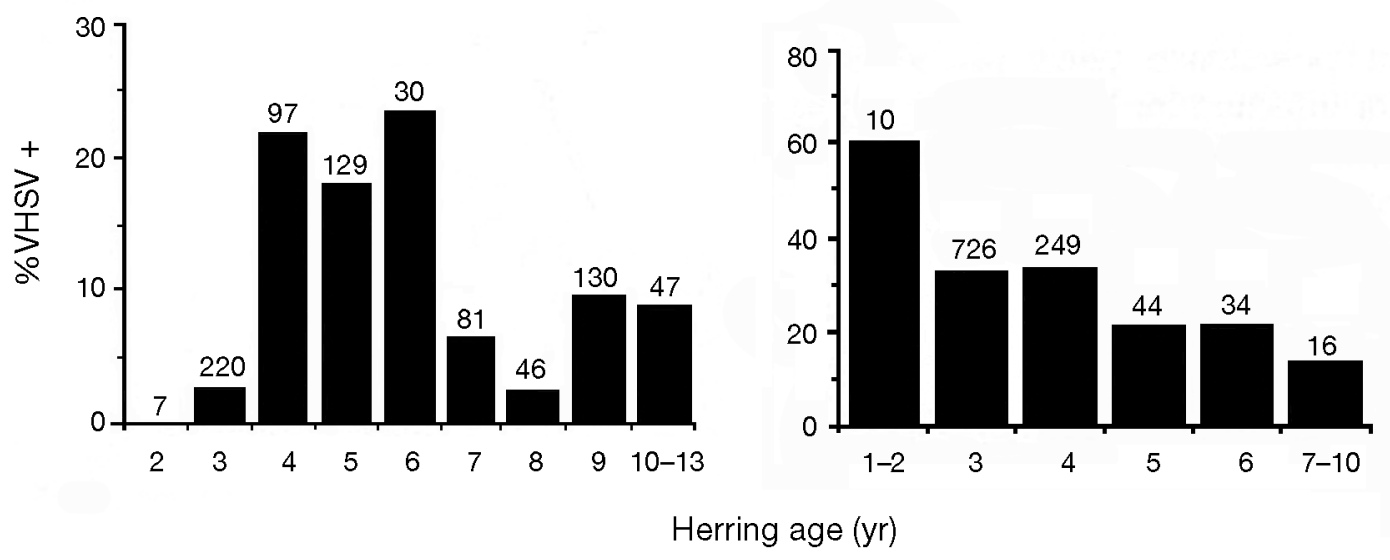

Fig. 1. Clupea pallasi. Average values for VHSV infection rates by year class in Pacific herring confined in spawn-on-kelp holding pounds from Prince William Sound (PWS) in 1997 (left) and 1998 (right). Note that these figures represent average prevalence values by year class. Peak prevalence values are given in the text. Numbers above vertical bars indicate sample size. Reproduced from Hershberger et al. (1999, their Figs. 4 [left] \& 8 [right])

tanks after capture and the subsequent infection of other fish in close proximity that had been subjected to the stress of capture and captivity. Hershberger et al. (1999) found that VHSV infections in herring confined in PWS SOK holding pounds (net pens) peaked in prevalence between 1 and $4 \mathrm{~d}$ or 6 and $8 \mathrm{~d}$ during studies in 2 consecutive years.

Herring reared in captivity that have no prior exposure to the virus are highly susceptible to waterborne challenges with VHSV, with mortality approaching $100 \%$ and limited increase of resistance until $2 \mathrm{yr}$ of age (Kocan et al. 1997). Kocan et al. (2001) measured concentrations of virus $>10^{3} \mathrm{pfu} \mathrm{ml}^{-1}$ in water from tanks used to transport fish to the laboratory. Although this viral concentration was demonstrated to be sufficient to transmit the disease to tank cohabitants, transmission in nature is clearly more complex in that the number of virus shedders and their rate of shedding is unknown and the dilution factor is much greater. Kocan et al. (1997) showed an average virus shedding rate for 10 captive fish of about $10^{6.5} \mathrm{pfu} \mathrm{h}^{-1}$, and a minimum water concentration of virus required for transmission in the range of $10^{1.5}$ to $10^{2.0} \mathrm{pfu} \mathrm{ml}^{-1}$. In nature, herring must be infected by the virus and naturally immunized through an unknown exposure regime. In fact, Hershberger et al. (2007) showed that exposure of Pacific herring larvae to VHSV at 44, 54, 76, and $89 \mathrm{~d}$ of age conferred progressively greater protection upon a second challenge of survivors with VHSV. In PWS, juvenile Pacific herring cohabit nursery and spawning areas with other species that are susceptible to VHSV, such as pollock and Pacific hake (Meyers et al. 1999). This cohabitation and the shedding of virus from small numbers of older infected herring and other species during the spring spawning season or other periods of stress may help perpetuate the infection and con- tribute to the acquisition of immunity by surviving larval and juvenile herring.

Kocan et al. (1997) measured the rates at which virus was shed from captive herring and hypothesized that such rates could support large VHSV epizootics in schooling fish. Recruitment of Pacific herring into the pelagic adult population starts at age 3, well past the age-0 time period when VHSV infections appear to occur most frequently (Kocan et al. 2001). Viral epizootics in younger schooling fish are most likely to occur when there are dense aggregations in nearshore areas or close associations with spawning adult herring. These conditions often occur in nursery areas where other species of VHSV-shedding fish may also occur. At other times, the virus is either undetectable or present at very low prevalences and levels in most PWS herring (Marty et al. 2003, 2004). Whether concentrations of virus sufficient to cause epizootics actually occur in open waters is questionable, even if virus shedders are present and recruited fish are not immune. The virus concentration found in the 2001 tanks used by Kocan et al. (2001) need only be diluted by a factor of 100 to become undetectable $\left(0 \mathrm{pfu} \mathrm{ml}^{-1}\right)$. This effective dilution and the exposure risk would involve a complex set of variables including fish density, swimming speed, water flow rate, number of virus shedding fish, their rate of shedding, number of susceptible fish in the population, and loss of viral infectivity in seawater (Hedrick et al. 2003). All available evidence suggests that the most significant expression of titers and transmission of VHSV take place within stressed schools of juvenile fish or during spawning aggregations occurring in nearshore areas. In the case of virus shed by spawning fish, the concentration of virus in the water column appears to be low in that only $15 \mathrm{pfu} \mathrm{ml}^{-1}$ of VHSV has been detected in sea 
water near spawning free-ranging herring in PWS from only 1 of 4 water samples (Hershberger et al. 1999).

\section{Acquired immunity}

Kocan et al. (2001) demonstrated mortality in unexposed age-0 fish but strong immunity in other age-0 fish that apparently had acquired immunity against VHSV by natural exposure. Survivors of laboratory epizootics or groups of nonsusceptible wild age-0 fish were completely refractory to challenge with VHSV. The outcome of virus infection in previously unexposed groups of age-0 fish in nature would likely depend on host factors (e.g. strength of individual immune response) and environmental factors (e.g. degree of stress to which the fish were exposed, and the exposure concentration of VHSV). Presumably, if fish in nature were not subjected to a high degree of stress, they may become infected with VHSV and tolerate low-grade viral replication followed by resolution of the infection, resulting in survival and achievement of acquired immunity. In natural populations, an undetermined number of age-0+ fish likely die of VHSV infection in most years, but many fish survive the infection. The development of acquired immunity or resistance is well-documented in studies by Hershberger et al. (1999) and Kocan et al. $(1997,2001)$ in which, compared with older fish, most younger fish have less or no immunity to VHSV. However, as discussed by Kocan et al. (2001), the precise mechanism of acquiring this immunity is unknown.

\section{Subclinical infections versus clinical disease}

The highest prevalence of clinical disease and maximum severity of VHSV infection in adults in PWS are reported in pre-spawning herring. Hershberger et al. (1999) showed a decrease in prevalence rate between pre- and post-spawning PWS herring in 1998 (although only at $\mathrm{p}>0.10$ ), whereas Carls et al. (1998) and Thomas et al. (1997) reported that VHSV was isolated from pre-spawning but not post-spawning herring.

As with other primary fish pathogens, isolation of VHSV from herring tissue is not necessarily diagnostic of clinical disease. Below a certain tissue concentration of virus, herring are clinically healthy and, therefore, said to have a subclinical infection. Hershberger et al. (2006) considered herring clinically diseased when whole body tissue titers of VHSV exceeded $10^{4} \mathrm{pfu} \mathrm{g}^{-1}$ of tissue. Consequently, when excised spleen and kidney tissues from grossly normal fish require blind subculturing for test-positive virus isolation, the sampled fish are clearly healthy but subclinically infected. Results from the 1994 to 2002 PWS studies (Marty et al. 2003, 2004), using methods described by Meyers et al. (1994), indicated that samples requiring subculture had virus concentrations of $\leq 50$ particles $\mathrm{g}^{-1}$ of tissue. It should be noted that quantal assays using fluid medium overlays, rather than plaque assays (pfu) with semisolid medium, were used to facilitate blind passage of samples. However, the dilutions used to determine virus concentrations are equivalent between both assays. Consequently, based on a 9 yr study of more than 2900 Pacific herring (Marty et al. 2003, 2004), a more conservative virus concentration of $\geq 10^{3}$ particles $\mathrm{g}^{-1}$ appeared to be associated with clinical disease. In our review of the data, fish with virus concentrations lower than this threshold were considered clinically healthy.

For reasons yet unknown, no VHSV has been isolated from the 759 samples of PWS adult Pacific herring collected in the fall during 1993 to 2001 ( $\mathrm{n}=24$ to 160 per fall season) (Marty et al. 2003). Possibly, a noninfectious form of the virus may exist as described for another fish rhabdovirus, infectious hematopoietic necrosis virus (IHNV) (Drolet et al. 1995). IHNV is a primary fish pathogen causing disease in juvenile salmon of susceptible species, after which a similar eclipse period occurs in survivors, whereby the virus generally cannot be isolated from carrier fish until spawning (Meyers 1998). Truncated defective interfering particles were described as a 'latent' form of IHNV reactivated during the stress of spawning (Drolet et al. 1995). Alternatively, VHSV may be present in concentrations below the detection limit of cell culture, or the percentage of subclinically infected adult fish collected in the fall season may be too low for detection of a testpositive fish. There is no published evidence to support the argument that clinically normal adult fish having low levels of virus in the spring would develop disease and die, thereby removing these fish from the fall samples. The most likely scenario among these possibilities is that detection of low virus levels in apparently healthy fish indicates they are carriers with acquired immunity, which permits these fish to clear the virus (Hershberger et al. 1999) below detectable levels when sampled in the fall.

\section{Effect of environmental variables on VHSV prevalence and severity in PWS herring}

Water temperature is one environmental factor that may affect the prevalence of VHSV in herring populations. Marty et al. (2003) postulated that the warmer winter of 1997-1998, corresponding to an El Niño effect, was responsible for the increase in prevalence of VHSV detected in PWS herring. Water temperatures 
in PWS were reported by Foy \& Norcross (2001) to average about $2^{\circ} \mathrm{C}$ warmer in 1997-1998 than in the previous winter. This hypothesis is reasonable in that elevated winter temperatures (causing a subsequent increase in herring basal metabolic rate) at a time of limited food availability could result in weight loss and stress to the herring population. Conversely, it has also been hypothesized that herring exposed to lower than optimal physiological temperatures may be stressed and subsequently suffer an outbreak of VHSV (Traxler et al. 1999). Other studies have indicated that the range of VHSV may be restricted to the northeast Pacific by warmer seawater temperatures to the south (Hedrick et al. 2003).

Impact of the PWS spawn-on-kelp fishery on VHSV transmission

Hershberger et al. (1999) demonstrated that confinement of herring in pounds at a time when they are most susceptible to infection (i.e. stressed by spawning condition) can be damaging to the captive population by exacerbating the prevalence and severity of VHSV. Hershberger et al. (1999, p. 29) reported, 'The prevalence of VHSV among Pacific herring in SOK pounds consistently increased with confinement time in the pounds.' During this same observation period, healthy free-ranging herring from the same stocks had much lower virus prevalences, ranging from 0 to $17 \%$. Hershberger et al. (1999, p. 30) hypothesized that '...operation of inherently stressful SOK pounds during spawning years predominated by [younger] susceptible fish may amplify the role of VHS in this process [of cyclic population fluctuations to which clupeid stocks are prone, worldwide].'

\section{REASSESSMENT OF VHSV IN THE 1992-1993 PWS HERRING COLLAPSE AND FAILURE TO RECOVER}

The collapse of the PWS herring population that occurred between the fall of 1992 and spring of 1993 was unexpected. A majority of the forecasted herring failed to return to the spawning grounds: about $63 \%$ or 84000 US tons of the expected total of 134000 US tons were missing (Meyers \& Winton 1995). The missing fish appeared to represent all age classes, in that ageclass composition before and after the crash was similar (Fig. 2). At the time of the collapse, the age-structured assessment (ASA) model used by the Alaska Department of Fish and Game (ADFG) showed a continuously increasing population trend since 1978 (Marty et al. 1998). However, that model was later revised (Ashe et al. 2005) to show a population decline beginning in 1990, just after the oil spill (Thorne \& Thomas 2008). Another model revision argued for a decline beginning in 1992-1993 (Hulson et al. 2008) but was based on an overestimation of VHSV effect as shown in this review. PWS herring harvest increased from greater than 11000 US tons in 1990 to over 22000 US tons in 1992 (Ashe et al. 2005).

In 1994, 1 yr after the PWS herring collapse, Marty et al. (1998) began a multiyear study (1994-2002) and found that VHSV and skin ulcers were present in most years but only during the spring pre-spawn to spawning period. Their primary hypothesis was that 'VHSV was the most important cause of mortality...' in the population collapse (Marty et al. 1998, p. 16). This hypothesis was based on the first report of North American VHSV in herring in association with the PWS 1993 population collapse (Meyers et al. 1994) and the studies initiated in 1994 (Marty et al. 1998). Marty et al. $(2003,2004)$ later presented a model for VHSV in PWS herring that we believe used erroneous assumptions, incompletely analyzed data (later discussed in detail), and, as stated in the corresponding report (Marty et al. 2004) that was the basis of the published paper (Marty et al. 2003), resulted in invalid conclusions, e.g. 'Outbreaks of viral hemorrhagic septicemia have been cycling through the population every 4-5 years since 1989' (Marty et al. 2004, p. 3).

Except for studies initiated as a result of the EVOS in 1989 to 1991 (Marty et al. 1999), there was no continuous herring health and condition monitoring study in place until 1994, 1 yr after the failure of the population (Marty et al. 1998, 2003). As a result, the only study of herring mortality and disease conducted in the spring of 1993, when the population failure became evident, was that performed by the ADFG (Meyers et al. 1994, Meyers \& Winton 1995). A review of the findings of

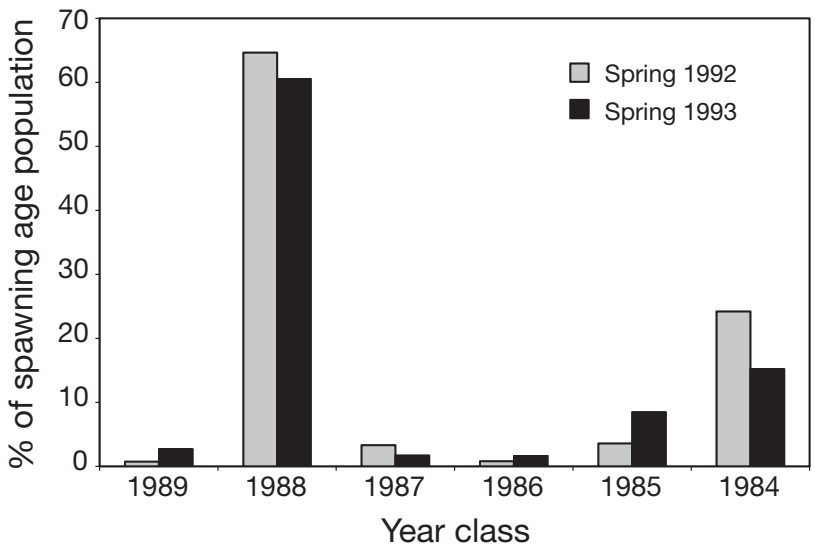

Fig. 2. Clupea pallasi. 1984 to 1989 year classes of PWS Pacific herring in spring 1992 compared with those in spring 1993 as a percentage of the total spawning age population in each year (Alaska Department of Fish \& Game unpubl. data) 
these reports and the conclusions of the authors is instructive, because they are the only factual evidence regarding the infectious disease status of PWS herring at the time of the 1993 event.

\section{Unusual absence of dead fish in spring 1993}

The most notable feature of the 1993 population crash was that there were no confirmed reports of massive herring mortality or large numbers of fish carcasses. Spawning age herring did appear in small numbers in limited locations in PWS in spring 1993 and a percentage of these fish exhibited skin lesions (Meyers et al. 1994). However, in general, the fish simply did not appear at expected spawning areas. The absence of any evidence for significant fish mortality was highly unusual for the loss of 84000 US tons of herring biomass when compared with other documented epizootics in fish where mass mortality has been typically observed in large bodies of water. These other reports include epizootics caused by Type IVa VHSV in clinically diseased Pacific herring (Meyers et al. 1999, Traxler et al. 1999), epizootics recently caused by the Type IVb strain of VHSV in several Great Lakes fish species resulting in large fish kills (Elsayed et al. 2006), and the death of tens of thousands of fish in other anecdotal reports. Instead, this absence of dead fish in PWS suggests a more chronic mortality in PWS, where the loss of large numbers of weakened herring in poor body condition occurred gradually over the 1992-1993 winter. Large numbers of herring that did not materialize on the spawning grounds has also been documented from another site in Alaska. In spring 2004, approximately 9000 US tons of herring that were forecasted to spawn in Behm Canal near Ketchikan did not appear, and there was no indication of herring mortality (ADFG unpubl. data).

\section{VHSV testing conducted on PWS herring in 1993}

Five-year-old herring (1988 year class) were expected to dominate the age structure in biomass of the missing fish in 1993 (Meyers et al. 1994). This fact was consistent with the historical 4 yr cycle of year-class dominance seen in PWS herring from the mid 1970s through the early 1990s, as established by ADFG stock assessments (Pearson et al. 1999). The age structure of the herring that did return in 1993, having the dominant 1988 year class, was similar to the age structure before the decline; thus, the loss of herring affected all adult age classes equally (i.e. those that were 3 to $8 \mathrm{yr}$ of age in 1992) (Fig. 2). Although very few of the expected herring actually returned, Meyers et al. (1994, p. 27) found that of the herring that '...did return, $15 \%$ to $43 \%$ had varying degrees of external ulceration or hemorrhage beneath the skin, at the bases of fins and around the vent, accompanied by lethargic swimming behavior.'

Meyers et al. (1994) received herring for necropsy collected from 3 locations in PWS (Graveyard Point, Red Head and Virgin Bay); however, only the fish having visible lesions from 2 of the sites were tested for the virus. Also examined was a group of adult herring with lesions from Barling Bay (Kodiak Island), a group of juvenile herring originating from Auke Bay (Juneau) that developed lesions while captive in an experimental tank, and adult herring without lesions collected as a control group near Admiralty Island (near Juneau).

Among PWS herring collected at Graveyard Point, Meyers et al. (1994) found one out of 2 pools of fish with lesions ( $\mathrm{n}=5$ fish per pool) were test-positive for VHSV. Most of these fish had not spawned. Both pools of fish with lesions from Red Head in PWS were test-positive for VHSV. Although the pools indicated virus-positive fish from the sample, the results did not allow a precise estimation of prevalence. From a total of 20 fish (4 pools, $n=5,3$ of 4 pools VHSV-positive) a minimum of 3 and a maximum of 15 test-positive fish could account for the results, resulting in an estimated prevalence range of 15 to $75 \%$. However, the higher percent prevalence is not representative of free-ranging fish (see the following section). The tissues were pooled from multiple fish collected for virus testing by cell culture to reduce effort. This required that results be reported as a less precise range of possible prevalence, because if a pooled result was positive, it could only be said that at least one fish in the pool was positive.

\section{Sample bias in 1993 tested PWS herring}

The samples evaluated by Meyers et al. (1994) were biased in 3 ways. First, by necessity, samples were collected from the limited portion of herring returning to spawn in PWS. Secondly, the testing favored fish with lethargic behavior and lesions because they were most available for capture and more likely to harbor a potential causative agent, and because there was further selection of these fish for lesions prior to and after receipt at the laboratory. Finally, the sample group of fish from Red Head, having both pools positive for virus, represented fish recently released from SOK pounds, which most certainly resulted in increased prevalence and levels of virus not representative of free-ranging fish. Therefore, a prevalence rate of $15 \%$, and certainly the upper end of the range of $75 \%$, most likely overestimated a true randomly determined population prevalence of VHSV for 1993, as was also true for the proportion of fish with lesions. 


\section{VHSV disease in other locations in 1993}

One of 2 pools of adult fish with lesions from Barling Bay (Kodiak Island) were test-positive for VHSV, while no virus was detected from 2 pools of adult herring collected from Oliver Inlet (Admiralty Island) (Meyers et al. 1994). Additionally, individual testing of 46 experimentally held juvenile herring from Auke Bay indicated 20 were test-positive for VHSV (Meyers et al. 1994). Although these latter fish were normal in appearance when captured by dip net, the stress of captivity apparently triggered viral shedding, resulting in epizootic mortality and an artificially elevated viral prevalence. Therefore, the viral prevalence is irrelevant but its detection in Auke Bay herring is not. Collectively, these data indicated that VHSV was associated with lesions in one other wild population of herring (i.e. Barling Bay) and that the virus was present in 2 widely separated Alaskan populations of herring other than PWS during the spring of 1993.

\section{Corrected method of calculating threshold VHS prevalence values}

The reported annual prevalence of VHSV (Marty et al. 2003) included virus-positive samples from clinically healthy fish that would be expected to survive (Table 1). In other words, the data were not corrected by a virus threshold analysis and, therefore, the reported prevalence values overestimated the proportion of fish expected to express clinical disease and die from VHSV. Use of a threshold for considering only diseased fish is a standard method for the evaluation of disease effects and was applied to evaluate the impact of Ichthyophonus hoferi infection in PWS herring in the ADFG ASA model by Moffitt (2006) and by Marty et al. (2003, 2004). Hershberger et al. (2006) considered that VHSV titers must be at least $10^{4} \mathrm{pfu} \mathrm{g}^{-1}$ tissue to indicate a clinically diseased fish, whereas Marty et al. (2003) indicated that fish with severe VHSV infection had titers $\geq 10^{3} \mathrm{pfu} \mathrm{ml}^{-1}$. We chose the more conservative titer for calculating threshold prevalence for VHS (Table 1). Examples of clinically healthy fish that were virus-positive were those samples requiring a 'blind passage' to develop cytopathic effect (CPE) and successfully isolate virus. In these samples, the estimated virus titers of 50 particles $\mathrm{g}^{-1}$ or less were at the detection limits of the cell culture assay. Even when these low-titered fish were included (Marty et al. 2003, 2004), the overall virus prevalence values were still relatively low. When these values were filtered to eliminate clinically healthy fish likely to survive such lowgrade infections, the prevalence values were reduced by nearly one-half, from an average of 5.7 to $2.9 \%$ from 1994 to 2002 (Table 1).

\section{Evaluation of skin ulcers as indicators of VHSV disease}

Examination of virological data indicates that the presence of skin lesions, ranging from skin and fin reddening to ulcers, does not provide a reliable diagnosis

Table 1. Clupea pallasi. Prevalence values of VHSV and skin ulcers (severe focal skin reddening: sevFSR) in Pacific herring from Marty et al. $(1998,2004)$ and T. R. Meyers (unpubl. Alaska Department of Fish \& Game [ADFG] laboratory reports), and values based on same raw data corrected for threshold virus concentration and VHSV-associated ulcers. Threshold value of $10^{3}$ particles $\mathrm{g}^{-1}$ of tissue used for determining calculated VHS prevalence, based on tissue concentration from spleen-kidney samples required to produce disease (T. R. Meyers unpubl. data). VHSV-associated ulcers are those that were VHSV-positive or that were from fish with test-positive spleen-kidney samples. nt: not tested

\begin{tabular}{|c|c|c|c|c|c|c|}
\hline \multirow{2}{*}{ Year } & \multirow{2}{*}{$\begin{array}{c}\text { ADFG } \\
\text { report }^{\mathrm{a}} \text { no. }\end{array}$} & \multirow{2}{*}{$\mathrm{N}$} & \multicolumn{2}{|c|}{ VHSV and calculated VHS prevalence (\%) } & \multicolumn{2}{|c|}{ SevFSR (ulcer) prevalence (\%) } \\
\hline & & & Reported VHSV & Calculated VHS & Reported & VHSV-associated \\
\hline 1994 & $94-0589$ & $233(227)^{b}$ & 4.7 & 4.3 & 3.0 & 2.1 \\
\hline 1995 & $95-0576$ & 259 & 1.9 & 0.4 & 3.1 & 0.4 \\
\hline 1996 & $\begin{array}{c}96-0568 \& \\
96-0574\end{array}$ & 260 & 0.0 & 0.0 & 1.5 & 0.0 \\
\hline 1997 & $97-0567$ & 260 & 14.6 & 6.9 & 0.0 & 0.0 \\
\hline 1998 & $98-0575$ & 250 & 13.6 & 6.0 & 3.2 & 1.2 \\
\hline 1999 & $99-0564$ & 300 & 1.0 & 0.0 & 0.6 & nt \\
\hline 2000 & $00-557$ & 300 & 0 & 0.0 & 0.7 & 0.0 \\
\hline 2001 & 01-0548 & 300 & 1.7 & 1.7 & 0.7 & nt \\
\hline 2002 & $02-544$ & 300 & 14.0 & 7.0 & 0.7 & nt \\
\hline Average & & & 5.7 & 2.9 & 1.5 & 0.6 \\
\hline
\end{tabular}


of VHSV infection, although severe focal skin reddening (sevFSR) or ulcers have been equated with VHSV infection. Skin lesions such as hemorrhages and ulcers may be caused by other etiologies (Meyers \& Winton 1995). These ulcers are indistinguishable by visual examination from skin lesions associated with VHSV. Skin ulcers and spleen-kidney pools of PWS herring were not individually cultured for the virus in 1993, but were in 1994 (Meyers \& Winton 1995). Among 26 herring with skin lesions, $8(31 \%)$ were test-positive for VHSV by either excised lesion culture or spleen-kidney pool culture. Conversely, 18 of the 26 fish (69.2\%) were test-negative for virus by either lesion culture or spleen-kidney pool culture.

Marty et al. (2003) modeled survival in PWS herring using an ulcer prevalence multiplier of $\beta=70$, where $\beta$ was stated to represent the 'proportion of the infected population that dies from a particular pathogen' but $\beta$, as used in the model, was actually an arbitrary weighting factor. A more refined model (Hulson et al. 2008) estimated mortality in PWS herring using a $\beta$-value as a disease coefficient or weighting factor that ranged between 0.5 and 2.0. Although review of these models is beyond the scope of the present paper, we emphasize the importance of incorporating the correct data that represents only herring with VHSV-associated ulcers. To accomplish this objective, we reevaluated the ADFG raw data, and included only skin lesions that were either virus-positive in cell culture or were from fish that were test-positive for VHSV by spleenkidney samples (Table 1). This adjustment may still result in an overestimation of VHSV-related ulcers, because fish with test-negative skin lesions but organ titers of virus may have developed the skin lesions from some other cause. Our re-analysis of virological data from all skin lesions and spleen-kidney pools tested from PWS herring from the 1994 to 2002 data (Marty et al. 2003, 2004) showed that, on average, only $18.3 \%$ of skin lesions could be attributed to or associated with VHSV. This proportion is derived by dividing the re-evaluated values by the original values for the calculated prevalence of VHSV associated ulcers (2 right-hand columns in Table 1). We corrected the data for skin ulcers tested during 1994 to 1998 to eliminate all lesions having no test-positive association with VHSV, but included fish having skin lesions with only low VHSV kidney-spleen titers. There are 3 yr of data (1999, 2001, and 2002) when skin ulcers were not tested for virus.

A reasonable conclusion regarding skin ulcers would be that in 1994, nearly $70 \%$ (Meyers \& Winton 1995) of observed skin lesions in PWS herring could not be associated with VHSV and were likely due to other causes. In the absence of other data, these findings suggest that in 1993, the majority of the ulcers and other skin lesions observed in herring from PWS also were not associated with VHSV but were likely caused by environmental factors or other opportunistic pathogens infecting fish severely weakened by poor nutritional condition and spawning stress. Although the cause(s) of all the skin lesions observed in herring collected during spring 1993 has not been determined, any skin ulcerations would likely have been fatal, causing electrolyte imbalance and osmoregulatory shock.

Lack of correlation between ulcer prevalence and detection of virus in herring is best observed in the reported outbreak years of 1997 and 2002 (Marty et al. 2003) when virus prevalence levels were among the highest observed with no or very few ulcers observed (Table 1). Therefore, does VHSV really cause skin ulcerations in herring? We suggest that, in juvenile herring, there is prevalent skin and fin hemorrhaging but no skin ulcers based on the lack of ulcers in controlled experimental infections (Meyers et al. 1994, Kocan et al. 1997). In adult fish, the disease is more chronic and associated ulcers have been observed, in some instances with isolation of VHSV from the ulcers but not from the visceral organs. In these few cases, perhaps the virus can contribute to ulcer formation by infecting the skin as a portal of entry (Meyers \& Winton 1995).

\section{Evaluation of the correlation between VHSV prevalence and severity}

A positive correlation would be expected between prevalence of a pathogen and severity of clinical disease if the disease has a measurable effect on the infected individuals. This relationship should occur, because as the total number of cases (infected fish) increases, the proportion of severely affected fish would also be expected to increase. This should happen over a short time because of the brief incubation period of VHSV in Pacific herring. However, in contrast to such an expectation, there is a very low, nonsignificant correlation value (calculated in all cases using the Pearson product moment correlation coefficient) (Venables \& Ripley 1997) between the prevalence and severity data (prevalence of VHSV by spleen-kidney culture and prevalence of skin lesions) reported by Marty et al. (2003) ( $\mathrm{r}=0.0967, \mathrm{p}=0.801)$. When the data are corrected by applying the threshold criteria and including only skin lesions that were VHSV-associated, the correlation coefficient between prevalence and severity increases, but still does not approach statistical significance $(r=0.3743, \mathrm{p}=0.321)$ (Venables \& Ripley 1997). This analysis indicates that the prevalence of VHSV reported was not correlated 
with outbreaks of clinical disease in herring. This fact was also indicated by Marty et al. (2004, p. 9): 'In 2002, the prevalence of VHSV (14\%) was among the highest of the 9 years studied, but relatively low ulcer prevalence $(0.7 \%)$ provided evidence that adult fish were not significantly impaired by the VHSV outbreak.' Thus, the data fit the expectation that VHSV has had little effect on recruited adult herring.

\section{Relationship of VHSV and calculated VHS prevalence with concurrent herring biomass and recruitment}

The graphical comparison of VHSV and calculated VHS prevalence values with herring biomass shows that these rise and fall in unison (Fig. 3). Statistical evaluation of the correlations between concurrent total biomass of recruited fish and VHSV and calculated VHS prevalence levels yields non-significant positive values (VHSV prevalence estimates: $\mathrm{r}=0.559, \mathrm{p}=$ 0.118 ; calculated VHS prevalence estimates: $r=0.442$, $\mathrm{p}=0.258$ ) rather than the expected negative correlations if VHS prevalence in a given year affected the concurrent biomass. This further indicates that VHS had no effect on the measured adult biomass in the year of the prevalence estimate.

The PWS herring biomass estimate was essentially stable around 35000 US tons from 1997 to 1998 in spite of a claimed outbreak of VHS in 1997 and 1998 (Marty et al. 2003, 2004). There was no drop in 1998, as would be expected if VHS had a mortality effect in 1997, which was a year of increased VHSV prevalence. The drop from 1998 to 2001 cannot be attributed to VHS, because the biomass decline to about 12000 US tons in

2001 was far greater than could be accounted for by the low prevalence and severity indices of VHS during these years (severity index defined as the prevalence of VHSV-associated skin lesions). In 1998, the prevalence and severity indices were 6.0 and $1.2 \%$, respectively, using calculated VHS prevalence based on the VHSV threshold value and VHSV-associated ulcer data. From 1999 to 2001, when annual prevalence values were less than $2 \%$ using either the VHSV data or the calculated VHS data, herring biomass declined each year. Finally, when the third alleged VHS outbreak occurred in 2002 (Marty et al. 2003, 2004), the herring biomass estimate actually showed an increasing trend, rising to over 16000 US tons in 2002 and over 23000 US tons in 2003 (Ashe et al. 2005).

We also calculated the correlation coefficient of both VHSV and calculated VHS prevalence on biomass $1 \mathrm{yr}$ after VHSV prevalence estimates for 1994 to 2003, to ensure that the 'no effect' or lack of correlation between adult biomass and VHSV and VHS prevalence was not an artifact of sampling time (i.e. the biomass could have decreased from VHS deaths after the spring sample). Again the correlation values (Venables \& Ripley 1997) were positive, rather than the expected negative, and non-significant: $\mathrm{r}=0.386$ and 0.303 and $\mathrm{p}=0.305$ and 0.428 for the correlation between VHSV and calculated VHS prevalence and biomass, respectively.

\section{Relationship between VHSV prevalence and PWS herring recruitment}

A more relevant comparison is that of VHSV and VHS prevalence to recruitment of 3-yr-old herring, because the virus has a greater negative effect on mostly age- 0 and possi-

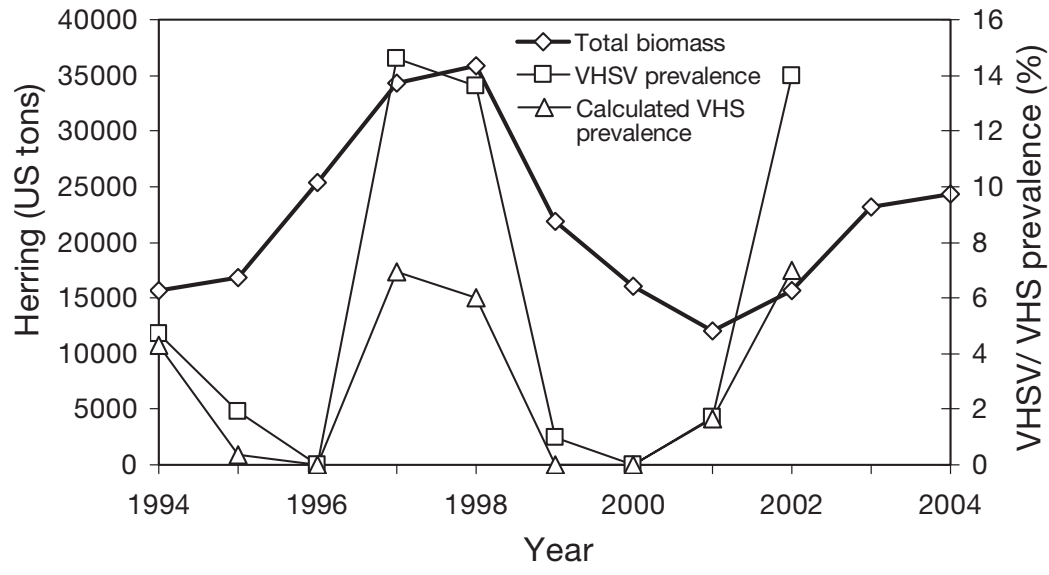

Fig. 3. Clupea pallasi. Age-structured assessment model of PWS herring total biomass, all year classes (3 to 9 yr old) for 1994 to 2004 data (Moffitt 2006) and both VHSV and calculated VHS prevalence values (viral prevalence data from Table 1) bly older pre-recruited juvenile fish (Kocan et al. 1997). Therefore, we compared VHSV and VHS prevalence with current recruitment of 3-yr-old fish (estimated pre-fishery total abundance) (Moffitt 2006), as well as lagged recruitment of 3 -yr-old fish 1 , 2 , and $3 \mathrm{yr}$ into the future (Table 2). The lagged recruitment index showed a weak negative correlation with VHSV prevalence using both VHSV (Marty et al. 2003) and calculated VHS prevalences, but none were significant ( $\mathrm{p}>0.05$ ) (Venables \& Ripley 1997) (Table 2).

Overall, the prevalence and biomass data do not suggest a strong role for VHSV in mortality of the 
Table 2. Clupea pallasi. Comparison of VHSV and calculated VHS prevalence and recruitment of 3-yr-old PWS herring in the current year and 3 subsequent years. ADFG (Alaska Department of Fish \& Game) recruitment index from Moffitt (2006). Recruitment numbers are ADFG-estimated pre-fishery total abundance (millions of fish) for 3-yr-old herring. Relationship of VHSV or calculated VHS prevalence was compared with recruitment estimates in the current year and 1, 2, and 3 yr afterwards to test the effect in spawning fish on the subsequent recruitment of fish potentially exposed in nursery areas to VHSV from spawning fish. Total VHSV (Marty et al. 2003) or calculated VHS (Table 1) prevalences were tested for correlation with the current and 1-, $2-$, and 3-yr lagged recruitment. Results using the 2 prevalence estimates were similar, i.e. the 2 sets of results were highly significantly correlated $(\mathrm{r}=0.964, \mathrm{p}<0.001)$, and there was no significant negative correlation between VHSV and 3-yr-old fish recruitment in the current or forward years using the total VHSV or calculated VHS prevalence values. The lagged recruitment indices showed weak negative correlations with VHSV prevalence; however, none of the values were significant ( $p \geq 0.05$ )

\begin{tabular}{|c|c|c|c|c|c|}
\hline Year & ADFG recruitment index & Tested year relationship & Prevalence value tested & Correlation coefficient (r) & $\mathrm{p}$ \\
\hline 1994 & 54.63 & \multirow{2}{*}{ Current recruitment } & Total VHSV & 0.521 & 0.150 \\
\hline 1995 & 173.32 & & Calculated VHS & 0.460 & 0.213 \\
\hline 1996 & 133.29 & \multirow[b]{2}{*}{ Recruitment 1 yr later } & Total VHSV & -0.356 & 0.347 \\
\hline 1997 & 152.78 & & Calculated VHS & -0.188 & 0.628 \\
\hline 1998 & 74.54 & \multirow[b]{2}{*}{ Recruitment 2 yr later } & Total VHSV & -0.580 & 0.101 \\
\hline 1999 & 0.01 & & Calculated VHS & -0.514 & 0.157 \\
\hline $\begin{array}{l}2000 \\
2001\end{array}$ & $\begin{array}{r}25.39 \\
6.49\end{array}$ & \multirow{2}{*}{ Recruitment 3 yr later } & Total VHSV & -0.343 & 0.366 \\
\hline 2002 & 222.43 & & Calculated VHS & -0.291 & 0.448 \\
\hline 2003 & 60.28 & & & & \\
\hline 2004 & 27.23 & & & & \\
\hline 2005 & 44.65 & & & & \\
\hline
\end{tabular}

PWS herring population. Not unexpectedly, the prevalence and severity values were low for adult fish and not correlated with adult population biomass. We found only a weak, non-significant correlation between adult VHSV prevalence and recruitment of 3 -yr-old fish, by which time the fish may have been affected by other limiting factors. Although not statistically significant, these comparisons (Table 2) do emphasize a basic argument: VHSV likely has only a minor negative effect on recruitment, affecting mostly $0-, 1-$, and 2-yr-old herring exposed to virus via adult fish.

\section{Condition of adult herring prior to population collapse}

Examination of fisheries data collected by the ADFG showed an increasing biomass of PWS herring with declining spring body condition in the years prior to the spring 1993 population collapse (Pearson et al. 1999). Although the population model and hindcast population biomass were revised to show a decline starting in 1990 (Moffitt 2006, Thorne \& Thomas 2008), the data showing the decline in condition of herring from the mid-1980s have not changed. Meyers et al. (1994, p. 33) noted, with regard to the moribund herring examined in spring 1993, that '... all herring were smaller in size and weight than expected from projections based on samples taken during the previous fall bait fishery...'
Condition of PWS herring showed a declining trend starting in 1984 to 1987 , depending on the year class examined (Moffitt 2006). The average spring weights of 6-, 7-, 8-, and 9-yr-old fish were relatively stable from 1980 to peak weights in the mid-1980s, then

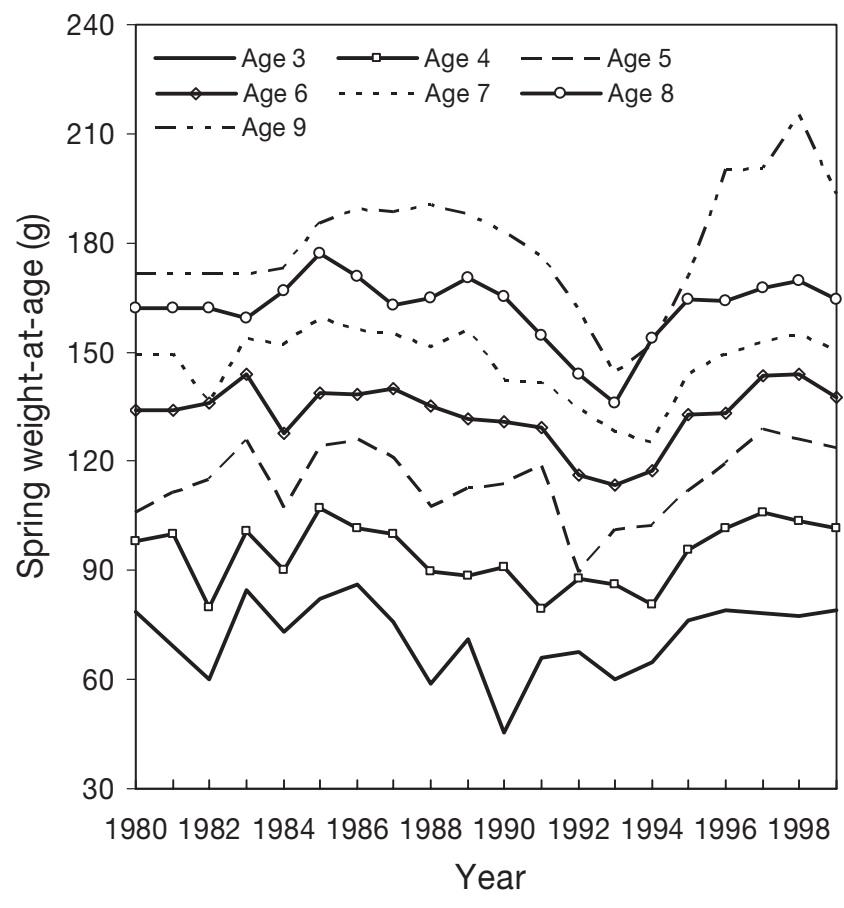

Fig. 4. Clupea pallasi. Spring weight-at-age (g) for PWS herring, 1980 to 1999 (ADFG unpubl. data) 


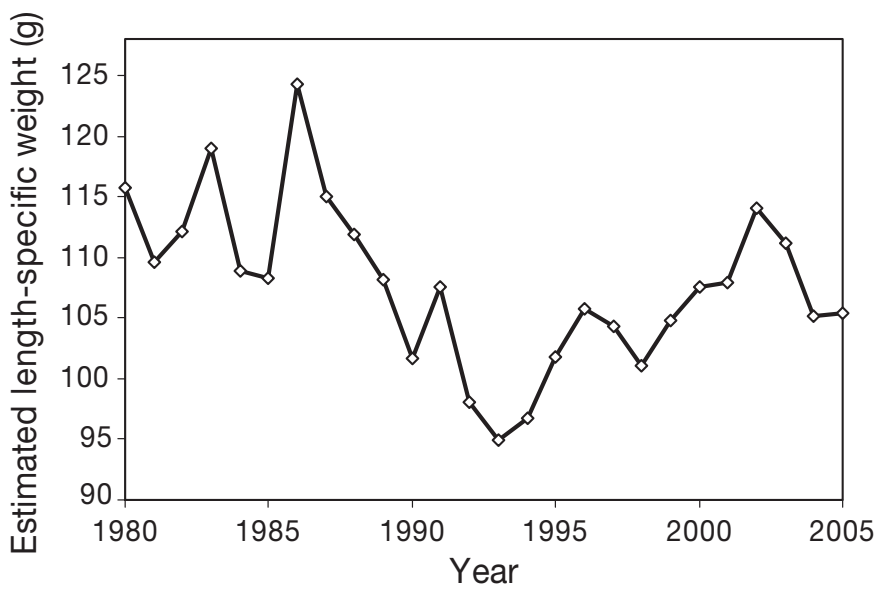

Fig. 5. Clupea pallasi. Estimated length-specific weight by year for PWS herring from 1980 to 2005. Data from Moffitt (2006) and other ADFG data report sources, based on analysis by method of Winters \& Wheeler (1994)

showed a declining trend until spring 1993, and rose again by 1994 for 3 of the 4 oldest age classes (Fig. 4). The average spring weights of 3-, 4-, and 5-yr-old herring showed higher year-to-year variation than other age classes, but also showed a downward trend from the mid-1980s to the early 1990s. The dominant 1988 year class fish (5-yr-old fish in spring 1993) showed a $25 \%$ decline in weight in spring 1992 compared with spring 1991, but then showed a rise in average weight of about 10\% from 1992 to 1993. However, only the remaining post-collapse portion of the fish was available to sample in spring 1993, and the $10 \%$ rise in weight is a consequence of selective mortality or limited samples available. In comparison, 3- and 4-yr-old fish showed lower average weights in 1993 than in 1992. Length-specific weight for 3- to 8-yr-old fish from PWS during the spring also showed a decline beginning in the mid-1980s, dropping to its lowest value in 1993, followed by a rising trend in the remainder of the decade (Fig. 5). Length-specific weight is defined as 'variation in the whole body weight (soma plus gonads) of herring of the same total length, after testing for differences in slope (form)' (Winters \& Wheeler 1994).

Increasing herring biomass in combination with declining spring weight-at-age and declining spring condition strongly suggest progressively unfavorable environmental conditions during winter over about an 8-yr period leading up to the year of the population collapse. These data are consistent with the conclusion of Pearson et al. (1999) that increasing herring biomass and decreasing food supply, resulting in poor body condition, possibly in combination with other factors, was responsible for the 1993 herring population collapse. Gradual mortality of herring likely occurred during the winter of 1992-1993, such that the majority of fish did not materialize to spawn in spring 1993.

\section{Historical presence of VHSV in Pacific forage fishes}

Despite published evidence to the contrary, there remains an implicit assumption that VHSV first appeared in PWS herring in 1993 or possibly in 1989 (Marty et al. 2003). There have been many instances in which emerging fish pathogens have been discovered and initially considered new or recently introduced when, in fact, their presence went undetected because of insufficient surveillance or because environmental conditions were not favorable for expression of the pathogen. In addition to the evidence for the long-term presence of North American VHSV, other historical data suggest that VHS outbreaks have occurred in Pacific herring and other forage species. Several thousand US tons of dead herring were found off the southeast coast of Vancouver Island, British Columbia, in February and March 1942 (Tester 1942). Marty et al. (1998) noted that many of the features described in the 1942 event (except for the observed mass mortality) were similar to the observations of PWS herring with VHSV in 1993. Traxler et al. (1999) reported that a large kill of pilchards (sardines) in the Strait of Georgia between January and February 1941 occurred with hemorrhagic areas observed on the skin and under the scales, again suggesting that this mortality could have been related to a VHSV outbreak. Although the causes for these events were never determined, prior episodes of VHS disease are likely given the evolutionary evidence for the multi-century presence of the virus in the marine environment, the demonstrated wide geographic range of the virus in northeast Pacific herring, and the broad host range of the virus in the northern Pacific Ocean.

\section{Critique of the hypothesis that VHSV was the primary cause of the 1993 PWS herring collapse and the failure to recover}

The primary hypothesis of Marty et al. (1998, p. 16) was that 'VHSV was the most important cause of mortality...' in the population collapse, and these authors concluded that VHSV was a major cause of morbidity in PWS herring during the spawning period of 1994. However, as we have argued, the data do not support this conclusion, but rather showed a relatively low prevalence of virus and low association of VHSV with skin lesions in sampled herring. In addition, the modeling prediction of the long-term effect of VHSV on PWS 
herring populations was based on incomplete evaluation of variables in the data, which included (1) no threshold analysis for determining annual virus prevalence associated only with clinically diseased fish, (2) the use of a prevalence statistic for skin ulcers that overestimated the number of lesions associated with VHSV-positive fish, and (3) no evaluation of the data by correlation analysis, which showed a very low value for the non-significant correlation between virus prevalence and disease severity and no significant relationship between VHSV prevalence and herring biomass or recruitment. Although their data showed increases of VHSV prevalence as detected by cell culture in 1997-1998 and 2002, no existing evidence or data analysis indicated that this higher prevalence had a negative effect on the herring population. Finally, Deriso et al. (2007) examined the Marty et al. (2003, 2004) model describing the role of VHSV in herring population abundance and found it lacking any significant effect due to weighting factors that may have biased their statistical results.

\section{Better fit to the data: VHSV is a secondary pathogen for adult Pacific herring}

Rather than assigning VHSV as a primary cause of the 1992-1993 PWS herring population collapse, there is a much more likely and conservative interpretation of the existing VHSV data and observations. This interpretation begins with the fact that herring condition declined for about $8 \mathrm{yr}$ starting in the mid-1980s. Also evident was the increasing herring biomass that peaked in 1992, and that food availability and herring condition declined so severely by the winter of 1992-1993 that fish actually lost weight over this period (Pearson et al. 1999). Thus, the root cause of the collapse was extremely poor body condition and starvation, resulting in chronic losses of herring occurring during the winter in combination with other adverse environmental variables that would include VHSV as a contributing factor in the younger herring. Although VHSV could have been elevated in fish that returned in spring 1993, any such increase in virus prevalence and severity was most likely a secondary effect of stress in an already weakened herring population. The missing herring in PWS encompassed all age classes, a fact inconsistent with the age-specific effects of VHS disease on herring (Hershberger et al. 1999). The younger fish that survived to spawn most likely sustained some unknown losses due to VHSV. The pooling of samples and a bias favoring the testing of fish with lesions from the small proportion of herring that appeared for spawning (Meyers et al. 1994) precludes a definitive conclusion that the prevalence of VHSV was elevated in 1993 significantly more than in years for which precise data are available.

This conclusion is quite different from attributing the 1993 population crash event to a single and primary cause of a VHSV epizootic. The critical evaluation of the data presented in the foregoing discussion provides compelling evidence that the North American strain of Type IVa VHSV is a widespread pathogen of Pacific herring beyond PWS. Many infected fish do not develop the disease and show a transient low level of virus followed by survival and the acquisition of immunity. The absence of positive correlation between the prevalence of sevFSR (ulcers) and detection of the virus by cell culture supports this contention. The data indicate that detection of VHSV in PWS herring is seasonal and associated with spawning stress. Thus, any effect due to VHSV appears to be on a small proportion of adult fish that manifest the viral disease during spawning each year and on juvenile herring in their first year of life. The severity of outbreaks is likely dependent on the degree of environmental stress. When environmental conditions are favorable, most fish probably survive the short-term infection and develop acquired immunity against future clinical disease (Hershberger et al. 1999, Kocan et al. 2001). Conversely, adverse environmental conditions would be expected to exacerbate losses of age-0 herring and, to a lesser extent, adult herring to VHSV. Meyers \& Winton (1995, p. 20 \& 21) made the reasonable conclusion that '...the epizootiology of VHSV in herring appears to be that of an opportunistic pathogen triggered by stress...' and 'It seems very unlikely that VHSV alone was responsible for the herring decline in PWS, but rather ... was a result of a much larger and more complex ecological interaction composed of many variables that include normal cyclical fluctuations of the herring population itself.' The authors' use of the term 'opportunistic pathogen' referred to adult herring. A subsequent study (Kocan et al. 1997) established that VHSV could be considered a primary pathogen for naive juvenile Pacific herring residing in nursery areas where virus exposure is most likely to occur.

Finally, Marty et al. (2004, p. 13) offer a statement with which we agree that contradicts their previous VHSV primacy conclusion: 'Disease prevalence determined only after an epidemic has been detected often provides the wrong information on the cause of the population decline.'

\section{USE OF HISTOLOGY TO DIAGNOSE VHS AND OIL EXPOSURE IN PACIFIC HERRING}

Histologic diagnosis in fish may be subject to inconsistency and lack of reference criteria. A systematic 
evaluation of the literature pertinent to VHSV in fish shows that diagnosis by histology is not definitive. Histological lesions have also been used to support claims about the effect of VHSV on PWS herring and the interaction of VHSV infection and oil exposure. Thus, an evaluation of the status of histological diagnostic standards used to identify infection by VHSV is required to determine the validity of such claims.

Diagnosis of disease is often qualified as 'presumptive' and 'definitive' based on the strength of evidence available and degree of sophistication of the methodology. In our discussion, morphologic descriptions of necrosis were evaluated based on the definitions provided for mammalian pathology (Jubb et al. 1993), as there are no such specific definitions for fish. Most importantly, the lack of definitive experimental pathogenesis studies, particularly from adult herring that comprise much of the field data, or the demonstration of virus particles, viral antigen, or nucleic acid in specific lesions, prevents the use of such histologically characterized lesions for a definitive diagnosis or even a strong presumptive diagnosis of VHSV infection. Consequently, the diagnosis of North American VHSV on the basis of histological lesions alone should be regarded as speculative. Although more research has been done on the strains of VHSV that are pathogenic to rainbow trout, resulting clinical signs and histopathologic changes are variable and these also cannot be used for a definitive diagnosis (McAllister \& Batts 1994).

\section{Hepatic and other lesions reported to represent VHSV infection or oil exposure}

The variable types of hepatic lesions in Pacific herring reported to be associated with VHSV (or in some cases associated with both VHSV infection and oil exposure) and those unassigned to cause are summarized in Table 3. Herring examined from oiled sites in PWS 2 wk after the EVOS had lesions in the liver described as coagulation necrosis, referred to as both focal and single-cell necrosis (Moles et al. 1993). The authors' observation was made prior to the discovery of VHSV in Pacific herring, but their conclusion is relevant to later claims of oil-VHSV interactions. However, their conclusion regarding oil and hepatic lesions is still unconfirmed by controlled research exposure: 'we are reasonably certain that the coagulative necrosis in affected livers was in response to oil toxicity' (Moles et al. 1993, p. 327)

Marty et al. (1999) examined herring collected $3 \mathrm{wk}$ after the EVOS from oiled and unoiled sites and reported hepatic coagulation necrosis, single-cell necrosis, the presence of karyomegaly, and bi- and trinucleated hepatocytes. These authors also used the term 'focal necrosis.' Marty et al. (1999, p. 421) described coagulation necrosis as 'characterized by rounding-up of individual hepatocytes, cytoplasmic hypereosinophilia, and nuclear karyorrhexis and karyolysis' supported by a photomicrograph of welldefined coagulation necrosis. Marty et al. (1999) re-

Table 3. Clupea pallasi. Publications reporting histological examination of the liver, type of lesion reported, and reported cause in Pacific herring. Significant kidney lesions reported are also listed. CN: coagulation necrosis; SCN: single-cell necrosis; HN: hepatocellular necrosis; HM: hepatocellular megalocytosis; RE: active reticuloendothelial cell foci, sometimes associated with single-cell necrosis and hemorrhage; EGL: eosinophilic granular leukocytes; HFN: hepatic focal necrosis

\begin{tabular}{|c|c|c|c|c|}
\hline $\begin{array}{l}\text { Herring source, } \\
\text { mo/yr, age }\end{array}$ & Reported hepatic lesion & Reported cause & Remarks & Source \\
\hline $\begin{array}{l}\text { PWS, } 04 / 89 \text { adult, } \\
2 \text { wk post-spill }\end{array}$ & $\mathrm{CN}, \mathrm{SCN}$ & Oil toxicity & $\begin{array}{l}\text { CN reported as } \\
\text { HFN and SCN }\end{array}$ & Moles et al. (1993) \\
\hline $\begin{array}{l}\text { Juneau 1985, } \\
\text { adult experimental }\end{array}$ & $\mathrm{CN}, \mathrm{SCN}$ & Oil toxicity & & Moles et al. (1993) \\
\hline $\begin{array}{l}\text { PWS, 04/89 adult, } 3 \text { wks } \\
\text { post-spill }\end{array}$ & $\mathrm{HN}, \mathrm{CN}, \mathrm{SCN}, \mathrm{HM}$ & HN due to VHS & $\begin{array}{l}\text { HN includes } \\
\mathrm{CN} \text { and SCN }\end{array}$ & Marty et al. (1999) \\
\hline PWS, 10/90, adult & $\mathrm{SCN}, \mathrm{HM}$ & None & & Marty et al. (1999) \\
\hline PWS, 04/91, adult & $\mathrm{SCN}, \mathrm{HM}$ & None & & Marty et al. (1999) \\
\hline PWS, 04/93, adult & $\begin{array}{c}\mathrm{SCN}(10 / 67), \mathrm{RE}(23 / 67), \text { nephrosis } \\
\text { and necrosis }(24 / 44)\end{array}$ & VHS & & Meyers et al. (1994) \\
\hline PWS, 04/94 adult & $\mathrm{CN}, \mathrm{SCN}$ & VHS & & Marty et al. (1998) \\
\hline $\begin{array}{l}\text { Puget Sound, 05/95, } \\
\text { juvenile experimental }\end{array}$ & $\mathrm{CN}$, kidney necrosis & VHS & & Kocan et al. (1997) \\
\hline $\begin{array}{l}\text { Shelter Island, 04/94, } \\
\text { adult experimental }\end{array}$ & EGL, SCN, HFN, thrombosis & $\begin{array}{l}\text { VHS and/or } \\
\text { oil toxicity }\end{array}$ & $\begin{array}{l}\text { Authors specifically } \\
\text { did not use term CN }\end{array}$ & Carls et al. (1998) \\
\hline PWS, 04/92, adult & SCN, HM & None & & Kocan et al. (1996) \\
\hline
\end{tabular}


ported that herring hepatic lesions from 1989 analyzed for differences in collection site were not significantly different between oiled and unoiled sites. The authors retrospectively concluded that the hepatic necrosis was probably a result of VHSV, a weakly presumptive conclusion without demonstration that the virus was actually associated with the observed hepatic lesions.

Marty et al. (1999) also examined herring from PWS collected in 1990 and 1991 and reported hepatic single-cell necrosis and hepatocellular megalocytosis. There was no discussion regarding whether or not the reported karyomegaly (normal in some species) and multinucleated hepatocytes were normal or abnormal for herring. Once more there was no statistically significant difference between oiled and unoiled sites regarding the changes in the liver, and the authors concluded that hepatic necrosis was probably a result of VHSV. Again, this conclusion can only be considered as weakly presumptive without further evidence that VHSV was associated with the observed lesions.

Meyers et al. (1994) and Meyers \& Winton (1995) were the only authors to study and describe fish sampled during April 1993 when the collapse of the PWS herring fishery was first noted. External ulceration, skin hemorrhages, and a lethargic swimming behavior were noted in herring returning to the spawning grounds. Tissues from 95 fish were examined for virus by cell culture (pooled sample infection range was estimated at 15 to $75 \%$ virus-positive), and organs from 79 of these fish were examined histologically and compared with liver and kidney tissues of 10 virus-negative herring collected from Admiralty Island, Alaska. Meyers et al. (1994) and Meyers \& Winton (1995) speculated that the following lesions were associated with VHSV infection: passive congestion of the blood vessels and sinusoids of the liver $(85 \%)$, spleen $(68 \%)$, kidney $(63 \%)$, and subcutis $(37 \%)$; diffuse single-cell hepatocyte necrosis $(15 \%)$; and active melanomacrophage foci of reticuloendothelial (RE) type cells in congested livers $(34 \%)$, kidneys $(18 \%)$, spleens $(6 \%)$, and subcutis $(63 \%)$ associated with necrosis in $10 \%$ of the active foci. Hemorrhage was reported in kidneys $(51 \%)$, spleens $(12 \%)$, and subcutis $(27 \%)$. Minor to extensive degeneration and pyknosis (necrosis) of the tubular epithelium of congested kidneys was reported in $55 \%$ of the herring, but necrosis was absent in the interstitial hematopoietic tissue of the kidney (as occurs for some infections by the European pathogenic strains of VHSV). Other incidental findings included the presence of several parasites at various prevalence levels. These reports are in contrast to other histological descriptions of Pacific herring from which VHSV was isolated (Carls et al. 1998, Marty et al. 1998, 1999), in that hepatic necrosis was minor and single-cell, rather than described as focal coagulation necrosis. The most significant acute lesion reported was renal tubular degeneration and necrosis, similar to lesions reported for the European pathogenic strains of VHSV.

In April of 1994, after which at least $63 \%$ of the biomass loss had already occurred, 212 adult herring were examined histologically by Marty et al. (1998). They reported focal hepatic coagulation necrosis in $2.8 \%$ and hepatic single-cell necrosis in $7.5 \%$ of the herring. Granulomatous inflammation (not associated with Ichthyophonus hoferi infection) comprised of pale foci of activated macrophages was also described in $34 \%$ of the kidney and $38 \%$ of the liver tissues examined. Histologically, these foci were similar to the active RE cell foci described by Meyers et al. (1994). Hepatic coagulation necrosis, meningoencephalitis $(3.3 \%)$, myocardial mineralization $(0.9 \%)$, and submucosal gastritis $(100 \%)$ were significantly associated with isolation of VHSV from a small percentage (11 of $233,4.7 \%$ ) of fish. Mild, renal interstitial-cell necrosis was reported in $8.5 \%$ of the fish, but was not statistically associated with VHSV infection. There was no finding of renal tubular degeneration. Reddening at the base of fins was also significantly associated with VHSV infection, though the virus was reportedly only isolated from 5 of 15 skin lesions. Skin ulcers were present in 7 of 227 (3.1\%) fish, but there was no report of histological examination of these lesions.

Kocan et al. (1996) described the comparative evaluation of reproductive success and histopathology of PWS Pacific herring taken in 1992 from previously EVOS oiled and unoiled sites. In summary, using multivariate analysis of variance (MANOVA), they did not find any significant site differences in lesion scores for liver, kidney, or spleen, but other organs were missing from the analysis. If the authors ignored splenic lesions, they found significant site differences in regard to hepatic single-cell necrosis. The authors themselves acknowledge that '...histopathological damage could not be conclusively correlated to previous oiling...,' (Kocan et al. 1996, p. 2392) nor was there any indication of VHS in the study.

Kocan et al. (1997) later described experimental VHSV infection of 'specific pathogen-free' (SPF) herring. The SPF status was based on incubation of eggs from artificially spawned wild herring and the rearing of hatched juveniles in pathogen-free, sand-filtered, UV-treated seawater. The histopathological changes following experimental VHSV infection included hepatic coagulation necrosis in 3 of the 6 groups of fish exposed to VHSV, although specific numbers of affected fish were not reported. They described moderate-to-severe multifocal hepatic coagulation necrosis 
in which pyknotic eosinophilic hepatocytes were interspersed with cells undergoing vacuolar degeneration. The authors also described moderate diffuse necrosis of splenocytes, infrequent multifocal necrosis of acinar cells in the pancreas, mild-to-moderate diffuse necrosis of kidney interstitial hematopoietic tissues and mesangial cells of the glomeruli and tubular epithelium, and mild-to-moderate diffuse necrosis of the epidermis and subcutis. However, there was no attempt to demonstrate virus in any of these lesions.

Carls et al. (1998) described an outbreak of VHSV in captive herring exposed to various concentrations of weathered crude oil. Coagulation necrosis was not mentioned, but the liver lesion described was '....moderate focal hepatocellular necrosis...' in 5 oil-treated fish and one control herring. Four of the oil-exposed fish were test-positive for VHSV. Carls et al. (1998) is the only study involving oil and VHSV infection in which vascular thrombosis is described in $19 \%$ of the oil-exposed herring, including one control fish. In addition, these authors found that, when the error rate for multiple independent analyses was corrected, the only statistically significant findings were an inverse correlation of hepatic perivascular eosinophilic granular leukocytes (EGLs) with oil dose and a positive correlation of splenic thrombosis with oil dose. Carls et al. (1998, p. 2307) concluded that 'Decreased prevalence of several types of inflammatory cells in livers as oil concentration increased was evidence for generalized immunosuppression in [oil] exposed Pacific herring.' This conclusion is not supported by the data, because the use of histological evaluation to quantify immune cells is a qualitative method and should only be used as a presumptive method to form hypotheses. A credible confirmation of their overall conclusion of immunosuppression would require quantification of the various types of leukocytes from live fish during the experiment by examining cell concentrations in the blood or by other quantitative methods. The authors indicated that a variety of other inflammatory lesions were lower in high-dose fish but that trends were not statistically significant. If immunosuppression was generalized, a reduction or absence of at least some of the other reported immunity-related observations (such as cholangitis and intrahepatic pericholangial leukocytes) would be expected, but no such reduction was reported. Finally, Carls et al. (1998, p. 2307) provided a comment that seems contradictory to their previous oil-exposure-related immunosuppression conclusion: '...decreased inflammation was more likely a non-specific response to stress than a specific response to VHSV or oil exposure.' The histological observations of Carls et al. (1998) do not provide definitive evidence for immunologic changes or hepatic damage that is related to either oil exposure or infection by VHSV.

\section{Use of clinical and histological findings to diagnose VHS in Pacific herring}

Based on our analysis of current literature, a presumptive diagnosis of clinical disease caused by North American VHSV could be considered in adult PWS herring when there are clinical signs of lethargy and skin reddening or skin ulcers accompanied by histological findings of renal tubular necrosis and degeneration. Active RE cell foci in the liver and other major organs that are associated with necrosis or hemorrhage may also be suggestive of VHSV infection. Similar RE cell hepatic lesions in resistant or recovering fish have been reported for other virus infections (Meyers 1980, 1983). In juvenile fish, systemic organ necrosis, including some form of hepatocellular necrosis, would also be required for a presumptive diagnosis. In both adult and juvenile herring, these lesions should be associated with cell culture isolations of VHSV at or above threshold tissue concentrations (Hershberger et al. 2006) suggestive of clinical VHS disease to make a diagnosis of clinical disease.

The diagnosis of VHS disease in Pacific herring based on hepatic lesions alone should not be considered definitive. This conclusion is based on the inconsistent morphological descriptions of these lesions and the reported absence of significant systemic necrosis or degeneration of other internal organs typical of clinical disease caused by a viremia, as reported in experimental VHSV infections of juvenile herring (Kocan et al. 1997). Clearly, VHS disease may be more severe or pathogenic in naive juvenile herring, but if the virus is to be diagnosed as a credible cause of mortality in adult herring, then other significant systemic lesions should be present.

The failure to conduct a definitive study demonstrating virus particles, viral antigens, or nucleic acid in lesions suspected to be caused by VHSV is a major deficiency in the existing research. This evidence must be established before definitive or even strong presumptive histological diagnoses of VHS in Pacific herring can be made by light microscopy alone.

\section{OIL INDUCTION OR EXACERBATION OF VHS IN PACIFIC HERRING - AN EVALUATION}

\section{Investigation of interaction of oil and VHS disease in herring}

Carls et al. (1998) presented preliminary results that oil exposure may induce replication and subsequent detection of VHSV in herring having subclinical infections of the virus. Later studies (Kennedy et al. 1999, Kocan et al. 1999, Sanders 2005) failed to repeat those 
results. We review the collective data for and against the hypothesis that oil induces VHS expression in Pacific herring based on these studies. Because certain stressors (i.e. handling and captivity) are known to cause outbreaks of VHSV, it is not unreasonable to posit that oil, as a mixture of potentially toxic components, could, at some sufficient concentration and duration of exposure, stress herring and induce further replication of VHSV to detectable levels in viruscarrier fish.

Demonstration of whether or not herring were exposed to a sufficient amount of EVOS oil in March and April 1989, or during a later date, to cause VHSV expression is a more specific question than 'Can oil at any level and duration stress herring and cause expression of VHSV and VHS disease?' The above 4 cited reports consist of 7 experimental attempts to link VHSV expression to oil exposure in herring and were the only studies found regarding oil exposure and viral expression in Pacific herring.

Carls et al. (1998) reported that experimental oil exposure was associated with inducing detectable levels of VHSV in Pacific herring that apparently were carrying the virus at previously undetectable levels. These authors used an oil generator consisting of an upwelling tube loaded with oiled gravel. The oil was heated overnight at $70^{\circ} \mathrm{C}$ to artificially weather it and '...simulate the composition of oil stranded on PWS beaches in 1989 after the Exxon Valdez oil spill...' (Carls et al. 1998, p. 2301) They reported a control and 4 exposure concentrations, which at the start of the experiment ranged from 0.03 to $58 \mathrm{ppb}$ total polycyclic aromatic hydrocarbons (TPAH) of artificially weathered crude oil. Wild adult herring were caught and acclimated in the laboratory for approximately $35 \mathrm{~d}$ prior to the experiment. After about the first $11 \mathrm{~d}$ of captivity, the authors reported that an unknown percentage of the herring developed signs of disease, resulting in less than $3 \%$ mortality. Four fish held in captivity prior to initiating the experiment were testnegative for VHSV by cell culture but were diagnosed with an external flavobacterial infection. Mortality was reduced following three $1 \mathrm{~h}$ formalin baths at $2 \mathrm{~d}$ intervals. Carls et al. (1998) conducted histopathological studies, virus assays, and other tests on the herring at the end of the $16 \mathrm{~d}$ experimental oil exposure, but fish that died during the experiment were not examined. Cumulative mortality was significantly different from controls only in the mid-oil dose (approximately $28 \mathrm{ppb}$ TPAH at initiation of the experiment). Heterogenous variance was also high in this treatment group, and when these results were removed from the data, the high oil dose then became significant. Of the VHSVpositive fish detected at the end of the experiment, none were detected in the control group. The treat- ment groups had VHSV prevalence levels of 6.4, 14.3, 16.7 , and $33.3 \%$ in the trace, low, medium, and high oil-exposure groups, respectively (Meyers \& Winton 1995; data not provided in Carls et al. 1998), leading Carls et al. (1998) to conclude that the prevalence of VHSV in fish sampled at the end of the experiment showed a correlation with initial oil dose. However, half of the test-positives in the high-treatment group were virus-positive only by blind subculture and, therefore, would be considered clinically healthy (i.e. the titer was less than 50 infectious particles $\mathrm{g}^{-1}$ ). As stated by Carls et al. (1998, p. 2303), '[virus] titer tended to decline with increasing [oil exposure] treatment, but was greatest in the mid-oil treatment.' This inverse relationship between VHSV titer and experimental oil exposure did not appear to support exacerbation by oil and, because of the high variance, Carls et al. (1998) concluded that there was no statistical difference in titers among treatment groups. They also reported that of the fish dying during the experiment, $97 \%$ had lesions consistent with published descriptions of VHSV-induced gross lesions in herring (Kocan et al. 1997, Marty et al. 1998). Carls et al. (1998) took no samples for virological analysis from these fish to confirm association of VHSV with the lesions observed, and their assumption that VHSV was the causative agent of the lesions is unsupportable, as discussed previously. They also reported Flavobacterium sp. infections in the experimental fish, a bacterium that can cause similar external lesions. Carls et al. (1998) also postulated that the histologically observed decrease in eosinophilic inflammatory cells in the liver in the high oil treatment was indicative of 'decreased immune surveillance,' which could lead to the expression of VHSV, but such a definitive immunological assessment cannot be made from histological observations.

The actual doses of oil delivered by Carls et al. (1998) are challenged by the results of Pearson (2005), which showed that the type of oil generator used by Carls et al. (1998) can create both oil droplets and dissolved oil components. Oil droplets would significantly add to the dose and toxicity of the oil treatments, as demonstrated by Pearson et al. (1985). The trace and low exposures of 4 to $13 \mathrm{ppb}$ that were used by Carls et al. (1998) bracketed the maximum mean environmental TPAH concentrations in open waters of PWS during the EVOS of $6.24 \mathrm{ppb}$ (Short \& Harris 1996), but did not result in cumulative mortality that was significantly different from the control treatment.

Carls et al. (1998) noted that in a companion study using post-spawning herring (Thomas et al. 1997), no clinical signs of VHSV disease and no mortality occurred that were related to oil dose. Carls et al. (1998, p. 2308) acknowledged that the results of their study '...do not prove causality... [between oil exposure and 
VHSV expression]', but they also state somewhat ambiguously that the results '... do show that hydrocarbon exposure, decreased tissue leukocytes, disease and mortality, are closely related.' Although the results are not definitive and the resulting hypotheses are clearly arguable, the most compelling data from Carls et al. (1998) does demonstrate a significant correlation of VHSV prevalence with the initial TPAH concentrations when compared with the virus-negative control group of fish. Carls et al. (1998) refer to studies that we review (Kennedy et al. 1999, Kocan et al. 1999, Sanders 2005) as potentially being more definitive in determining whether the toxic effects of environmentally relevant concentrations of crude oil on Pacific herring result in expression of VHSV. Those studies were underway at the time of publication of Carls et al. (1998).

Kocan et al. (1999) and Kennedy et al. (1999) performed 4 additional experiments that attempted to show an induction or enhancement of VHSV disease by oil exposure. Kocan et al. (1999) hypothesized that Pacific herring exposure to crude oil might result in increased susceptibility to initial virus infection or relapse of VHS in herring. In 2 experiments, Kocan et al. (1999) used age-0, age-1+, and laboratory-reared SPF herring (age not specified), and exposed the fish using Prudhoe Bay crude oil. This exposure is assumed to have been fresh oil, because no weathering treatment was reported. Kocan et al. (1999) used an oil generator similar to that described by Carls et al. (1998). Fish were exposed to $10-20 \mathrm{ppb}$ of oil for 14 to $21 \mathrm{~d}$ in the 2 experiments and challenged with between $2 \times$ $10^{2}$ and $5 \times 10^{3} \mathrm{pfu} \mathrm{ml}^{-1}$ of VHSV by immersion for $1 \mathrm{~h}$ following the oil exposure. These experiments failed to show any expression or exacerbation of VHSV by oil exposure. Kocan et al. (1999) concluded, 'No evidence could be found to support the hypothesis that exposure to oil resulted in increased susceptibility to VHSV in wild or laboratory-reared herring' (p. II-7) and 'No evidence for increased susceptibility, mortality or loss of disease resistance was observed in wild or laboratory-reared herring exposed to oil or synthetic corticosteroids, either prior to or following exposure to VHSV' (p. II-1).

Kennedy et al. (1999) performed 2 additional experiments with a similar objective, one using adult and the other using juvenile Pacific herring, employing the same type of oil generator used by Carls et al. (1998) and Kocan et al. (1999). Kennedy et al. (1999) exposed herring to an oil-water dispersion (OWD) of North Slope crude oil (also presumably non-weathered oil, but not specified), using a control group and 3 oil-dose ranges of 3 to $16 \mathrm{ppb}, 56$ to $85 \mathrm{ppb}$, and 178 to $328 \mathrm{ppb}$ TPAH for 21 and $28 \mathrm{~d}$. After 21 or $28 \mathrm{~d}$ of oil exposure, the fish were challenged with VHSV. In the experiment using adult Pacific herring, Kennedy et al. (1999, p. III-31) reported, 'No signs of VHSV infection were noted, and no mortality occurred in these fish.'

In the experiment using juvenile herring, Kennedy et al. (1999) reported, 'The results of these experiments were highly variable, and no dose-response effect of OWD exposure on herring mortality due to VHSV could be determined' (p. III-31), and alleged (p. III-31) that 'Both OWD and VHSV were acutely toxic to juvenile herring, however, both stressors together resulted in much higher mortalities' (Fig. 6). Examination of their data supporting the claim for an additive or synergistic effect shows that this interpretation was not statistically tested and is not valid. We performed a statistical analysis of the results, which had shown approximately $30 \%$ cumulative mortality when the fish were exposed to the OWD and VHSV, compared with $26 \%$ mortality when the fish were exposed to OWD alone. These results pertain only to the highest concentration of OWD (178 to $328 \mathrm{ppb}$ TPAH). No oil-VHSV interaction effect was reported for any lower oil-dose treatment.

Statistical evaluation showed that the effect shown in Fig. 6 (Kennedy et al. 1999, their Fig. 8) for the combination of OWD and VHSV is less than would be expected if the effects were additive. Because Kennedy et al. (1999) did not provide numerical data, we estimated the cumulative mortality from the graph (Fig. 6) as $30 \%$ for the combination of VHSV and OWD, $26 \%$ for the OWD treatment, $20 \%$ for the VHSV treatment, and $12 \%$ for the control treatment. Our statistical evaluation was conducted to determine the expected additive effect of OWD and VHSV. If 2 mortality sources act independently (an additive effect), then the probability of overall survival $(S)$ can be written as follows:

$$
S_{\text {Total }}=S_{\mathrm{OWD}} \times S_{\mathrm{VHSV}}
$$

and total mortality $(M)$ as

$$
M_{\text {Total }}=1-S_{\text {Total }}=1-S_{\mathrm{OWD}} \times S_{\mathrm{VHSV}}
$$

Rewriting survival as $1-M$, then

$$
M_{\text {Total }}=1-\left(1-M_{\mathrm{OWD}}\right)\left(1-M_{\mathrm{VHSV}}\right)
$$

and Eq. (1) becomes:

$$
M_{\text {Total }}=M_{\mathrm{OWD}}+M_{\mathrm{VHSV}}-\left(M_{\mathrm{OWD}} \times M_{\mathrm{VHSV}}\right)
$$

Calculation of Eq. (1), which is an algebraic equality (Skalski et al. 2005), provides a result of 0.408 , or $41 \%$ (as opposed to the reported $30 \%$ ), cumulative mortality expected if the mortality effects of OWD and VHSV were additive. If the effects were synergistic, the cumulative mortality would be expected to be higher than an additive effect, or higher than $41 \%$. This analysis shows that the effect reported for OWD and VHSV were not additive or synergistic. Based on this 


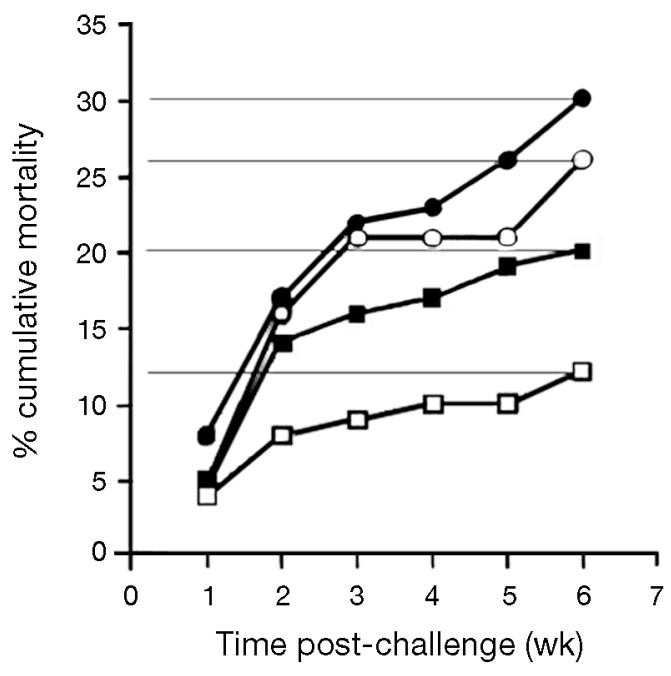

Fig. 6. Clupea pallasi. Percent cumulative mortality in Pacific herring exposed to VHSV and oil-water dispersion (OWD). $(\bullet)$ VHSV and OWD exposure; (O) OWD exposure only; ( VHSV exposure only; $(\square)$ control. Horizontal lines were added to estimate the numerical total cumulative mortality.

Reproduced from Kennedy et al. (1999, their Fig. 8)

analysis, Kennedy et al.'s (1999) statement that '... both stressors together resulted in much higher mortalities...' is also not supportable. Their observed effect is likely a result of experimental variation or could indicate an antagonistic effect of oil and VHSV infection. Thus, this experiment does not resolve the question of potential oil enhancement of VHSV infection, even at the very high OWD dose used, relative to the much lower measured oil concentrations found after the EVOS.

Sanders (2005) performed 2 additional experiments, one in adults and one in juvenile (age-0+) herring, which were undertaken in 1997 and 1998. These experiments also tested the hypothesis that an induction or enhancement of VHSV disease might be caused by oil exposure. The fish were exposed to the water soluble fraction of oil (WSFO) using an oil generator similar to that used by Carls et al. (1998), but loaded with silica biofilter rings that had been soaked in Prudhoe Bay crude oil. As with Kocan et al. (1999) and Kennedy et al. (1999), the exposure in the experiments conducted by Sanders (2005) is assumed to have been with fresh oil, as no weathering treatment was reported. Both age-0+ and adult fish were exposed to 'the maximum achievable concentration of WSFO' (Sanders 2005, p. 127 \& 129). The maximum achievable concentration of oil was controlled by the amount of oil that could be loaded into the oil generator, which was determined to be $120 \mathrm{~g}$ of oil.

TPAH levels were measured at 7 points over the course of the age- $0+$ experiment. Mean $( \pm \mathrm{SE}) \mathrm{TPAH}$ water concentrations in ppb for Day 0 (sampled within 10 min after initiation of exposure), Day 1, Day 2, Day 4, Day 7, Day 14, and Day 21 were, respectively, $82.82 \pm 1.68,9.69 \pm 1.02,5.00 \pm 0.32,6.63 \pm 3.60,3.03 \pm$ $2.34,0.42 \pm 0.11$, and 0.19 . No TPAH water concentration data are given for the adult experiment. It cannot be assumed that the TPAH levels for the adult experiment mirrored the juvenile study, as the oil generator did not produce consistent TPAH water concentrations despite no noted change in methodology. Measurements from other experiments included a Day 1 TPAH concentration of $321.0 \mathrm{ppb}$, and in another instance a Day 0 TPAH of $6.00 \pm 0.47$, followed by a Day 1 TPAH water concentration of $55.92 \pm 41.71 \mathrm{ppb}$. Both the magnitude and timing of the peak TPAH concentration differed between trials. Comparing these numbers with the Day 0 and Day 1 levels in the juvenile herring trial (Day $0=82.82 \pm$ 1.68 , Day $1=9.69 \pm 1.02 \mathrm{ppb}$ ) clearly illustrates the variation in TPAH water concentrations produced at the beginning of the herring exposure to WSFO, even though Sanders (2005) loaded the same amount of oil $(120 \mathrm{~g})$ into the oil generator.

After the initial peak WSFO exposure, TPAH levels fell rapidly, and, as documented in the trial with juvenile fish, experimental TPAH levels were then similar to the documented maximum mean environmental TPAH concentrations in open waters of PWS during the EVOS (6.24 ppb) (Short \& Harris 1996). Sanders (2005, p. 217) noted that, in her experiments, 'the water TPAH concentrations were higher than those reported for the EVOS at the peak of the experimental exposure and could be considered to have represented a worst case scenario for exposure following a spill.'

To test the hypothesis that an induction or enhancement of VHSV disease might be caused by oil, Sanders (2005) challenged the herring with VHSV through static bath challenge by lowering the water level and exposing the herring to VHSV for 1 $\mathrm{h}$, following the procedure of Kocan et al. (1997). The time of administration of the VHSV challenge was different for the 2 ages of fish. In the adult challenge study, the VHSV challenge occurred after the herring were exposed to WSFO for $21 \mathrm{~d}$, whereas in the juvenile study, the exposure to WSFO and VHSV overlapped, with the VHSV challenge occurring $7 \mathrm{~d}$ into a 21 d WSFO exposure (Sanders 2005). Adult herring were challenged with $1 \times 10^{4} \mathrm{pfu} \mathrm{ml}^{-1} \mathrm{VHSV}$, and juvenile herring were exposed to $1 \times 10^{5.5} \mathrm{pfu}$ $\mathrm{ml}^{-1}$ VHSV. Sanders (2005) intentionally used higher challenge doses of VHSV than had been used in previous work. For both the adult $(\mathrm{n}=480)$ and juvenile herring $(\mathrm{n}=480)$ studies, there were 4 treatment groups: control, WSFO-exposed, VHSV-challenged, and WSFO/VHSV-challenged. 
The results of the adult sequential exposure to WSFO and VHSV challenge demonstrated no statistical difference in cumulative mortality between the 4 groups, with cumulative mortality rates of $10.8 \%$ in WSFO-exposed, $11.6 \%$ in VHSV-challenged, and $17.6 \%$ in WSFO/VHSV-challenged, compared with $15.9 \%$ in control (Sanders 2005). Dead fish were not evaluated for tissue VHSV titer, so proportional mortality attributable to VHSV was not determined. Of the 319 herring tested for tissue VHSV titer, only 2 fish had detectable levels; one fish in the VHSV-exposed group had a tissue titer of $2.64 \times 10^{6} \mathrm{pfu} \mathrm{g}^{-1}$, and a second fish in the WSFO-exposed group had a tissue titer of $1.16 \times$ $10^{5} \mathrm{pfu} \mathrm{g}^{-1}$. There was no evidence of an increase in VHS disease (mortality) in the WSFO/VHSV-challenged fish. With no statistically significant difference in cumulative mortality between the groups, Sanders (2005, p. 213) concluded, 'Exposure of adult herring to WSFO, either alone or in conjunction with VHSV, had no significant impact on mortality.'

VHSV exposure for the juvenile challenge was conducted concurrent with WSFO exposure to test the hypothesis that 'combined exposure to WSFO and VHSV ... [would] be more likely to induce clinical VHSV if the WSFO were acting as an immunosuppressive agent' (Sanders 2005, p. 190). Although cumulative mortality was significantly greater in WSFO-exposed fish compared with controls, at the end of this experiment (63 d), there was no statistically significant difference in the cumulative mortality for the WSFOdosed/VHSV-challenged fish (64.8\%) compared with the WSFO-only group (68.9\%), or when these groups were compared with the VHSV-only challenged $(51.0 \%)$ fish. In addition, there was no statistical difference in cumulative mortality between VHSV-only challenged (51.0\%) and control (26.3\%) fish, possibly as a result of a reduction in sample size due to removal of fish for testing during the course of the experiment. In addition, the comparison was complicated by the unequal history and treatment of control and experimental groups prior to VHSV exposure. Proportional mortality attributable to VHSV, as determined by isolation from tissues, was only significantly different in the VHSV-challenged group, and only at $7 \mathrm{~d}$ post-challenge. There were no other significant differences in proportional mortality. The overall proportions of juvenile herring mortalities with a positive viral tissue titer were $10 \%$ for the control fish, $0 \%$ in the WSFO fish, $11.6 \%$ in the WSFO-exposed/VHSV-challenged fish, and $13.5 \%$ in the VHSV-only challenged fish. The $10 \%$ of the control group mortalities which were VHSV-positive reflect the fact that this experiment used wild fish with uncontrolled prior exposure to VHSV. There was no statistically significant difference in the proportion of dead juveniles testing VHSV-posi- tive between control, WSFO-challenged, WSFO/ VHSV-challenged, or VHSV-only challenged fish. Sanders (2005, p. 189) concluded that 'an increased susceptibility to mortality from VHSV infection with concurrent WSFO exposure was not evident during the experiment.'

Sanders (2005, p. 196) acknowledged that her findings did not support the proposed hypothesis that 'oil exposure might activate VHSV in sub-clinically infected and asymptomatic carrier fish.' She observed (p. 196), 'In this study, exposure to WSFO, in concentrations relevant to the PWS exposure, did not affect the apparent established immunity to VHSV in terms of morbidity or mortality.'

Exposure to WSFO also did not increase the susceptibility of herring to VHSV when challenged with a high concentration of virus. As Sanders (2005, p. 211) logically concluded, 'the inability to induce clinical disease following a challenge is in itself a measure of the immunocompetence of the population being challenged.' Ultimately, she extrapolated her findings to the expected effect on herring population levels, concluding, 'Thus, based on the experimental results, an impact at the population level would not be anticipated' (Sanders 2005, p. 213).

\section{Conclusions from oil and VHSV experiments}

Kocan et al. (1999), Kennedy et al. (1999), and Sanders (2005) described 5 separate experiments in which the authors acknowledge there is no relationship between oil exposures and VHSV induction or exacerbation, and a 6th experiment in which a suggested relationship cannot be statistically substantiated. In summary, these 6 experiments failed to show any expression or exacerbation of VHSV from exposure to oil. Although intriguing, the correlation of VHSV prevalence with oil exposure dose in Carls et al. (1998) must be considered as suggestive but unconfirmed data, since the results could not be repeated by other investigators (Kennedy et al. 1999, Kocan et al. 1999, Sanders 2005) under controlled laboratory conditions. The Carls et al. (1998) study was also confounded by high variability, lack of definitive diagnosis for the cause of herring mortality during the experiment, an undetermined percentage of fish with external lesions before the start of the experiment, and no significant differences in mortality between controls and a treatment group exposed to an OWD dose about 1.5 times higher than that reported from waters of PWS after the EVOS.

Within the experimental conditions reported, the cumulative results of these experiments do not confirm that exacerbation of VHSV infection in Pacific herring 
occurs at TPAH doses up to $328 \mathrm{ppb}$, a concentration much higher than those reported in water following the EVOS (6.24 ppb TPAH) (Short \& Harris 1996). Studies to date suggest that if oil exposure exacerbates VHS, the required oil dose concentration is substantially higher than that reported in PWS following the EVOS.

Also related to these conclusions is the spurious notion that there was an exacerbating effect of oil in 1989 causing VHS in 1993 and loss of the herring that did not return to spawn in PWS during 1993. This theory of 'delayed immunosuppression' (Kocan 1994) was advanced during the 1994 trial on behalf of plaintiffs against ExxonMobil (Kocan 1994). We could find no evidence in the scientific literature to substantiate the occurrence of delayed immunosuppression. Marty et al. (1998) and Elston et al. (1997), in evaluating health and disease of PWS herring in 1994, also concluded that there was no evidence to support this theory.

\section{Other study conclusions regarding the EVOS and diseases in PWS herring}

Marty et al. (1998, p. 38) also found no evidence to link their observation of other herring diseases with the 1989 EVOS: '...among VHSV, Ichthyophonus and 10 other common parasites, none were more prevalent in the 1988 and 1989 year classes than in the entire sampled population.' (The 1988 and 1989 year classes would have been the most likely to be negatively affected by any EVOS effects.) In their more recent work, Marty et al. (2003, p. 1259) also cast doubt on the role of oil in the 1993 PWS population crash and cite their earlier paper (Marty et al. 1998) in this regard: 'Explanations of the decline in 1993 remain controversial, but no scientific evidence directly links the oil spill to population decline (Elston et al. 1997, Marty et al. 1998).'

\section{CRITICAL SUMMARY}

\section{VHSV in Pacific herring}

VHSV is a widespread pathogen of Pacific herring in Alaskan waters and the northeast Pacific and occurs in many other marine fish species. Genetic studies (EinerJensen et al. 2004) of the virus suggest that it has been present in the North Pacific for several centuries. Isolation of low levels of VHSV in a relatively small (0 to $17 \%$ ) proportion of diseased and clinically healthy spawning herring or juvenile fish in the spring has been a recurring feature of herring biology in PWS and other sites in Alaska (Meyers et al. 1994, 1999, ADFG case report 94-0571 [unpubl.]). Epizootiological studies
(Meyers \& Winton 1995, Kocan et al. 1997, Hershberger et al. 1999, 2006, 2007) have provided evidence that juvenile fish become infected with virus shed from adults. Fish with virus titers below $10^{4}$ to $10^{3}$ are clinically healthy. Naive age-0+ herring are most susceptible to infection and disease. In natural populations, an undetermined number of juvenile fish likely die in most years, but a proportion survives and acquires immunity. Older adult herring become refractory to the virus and VHS disease from previous exposures. The severity of VHS outbreaks in herring is likely dependent on the degree of environmental stress. There also is a very low correlation between ulcer prevalence and detection of virus in herring, indicating that only a small percentage of ulcers in herring are caused by VHSV.

\section{PWS herring population collapse}

When the major PWS herring collapse was observed in spring 1993, the herring biomass had reached record proportions during the previous winter, and body condition was substandard following 8 yr of poor body condition during the winter. The bulk of herring mortality in PWS most likely occurred chronically during the winter of 1992-1993 when weakened fish died gradually from predation or other environmental causes, including secondary VHS in some of the younger fish. This multifactoral hypothesis is supported by the uniform loss of all adult herring age classes, most of which should have been relatively resistant to developing VHS disease, and the absence of observed mass fish mortality typical of other reported acute VHSV outbreaks in herring and other fish species (Meyers et al. 1999, Traxler et al. 1999, Hedrick et al. 2003, Groocock et al. 2007, Lumsden et al. 2007). The younger fish that survived to spawn sustained some unknown losses from an outbreak of VHS, the magnitude of which was not determined. This outbreak could have been more severe than in other years due to poorer body condition, but was likely overestimated as a result of pooling of samples and sampling bias in testing that favored fish with lesions.

\section{VHS studies during the post-collapse period}

A subsequent 9 yr study (Marty et al. 2003) regarding the long-term effects of VHSV on recovery of the PWS herring population showed fluctuating low to no viral prevalence in spawning fish typical of proportions detected by other studies (Meyers et al. 1994, Hershberger et al. 1999, 2006, Hedrick et al. 2003) in randomly sampled, apparently healthy, free-ranging fish. 
Analysis of data showed no credible evidence that these low viral prevalences had a negative effect on the herring population. This lack of negative effect was further emphasized by (1) additional analysis of the original data that included threshold prevalence for clinically diseased fish, which reduced the biologically significant virus prevalence by nearly half; (2) elimination of skin ulcers not associated with VHSV, which resulted in the determination that only one quarter of skin lesions examined were associated with $\mathrm{VHSV}_{i}$ (3) analysis of the correlation between VHSV prevalence and severity of disease, which indicated no significant relationship of virus prevalence with outbreaks of clinical disease; and (4) correlation of virus prevalence with biomass and recruitment, which indicated only minor, negative, non-significant effects on 0 - to 2-yrold herring exposed to virus via adult fish.

\section{Use of histology to diagnose VHS}

Histological diagnosis of VHS disease in Pacific herring should not be considered as definitive evidence based on hepatic lesions alone without evidence of virus association. This conclusion is based on the inconsistent morphological descriptions of these lesions and the reported absence of other significant systemic necrosis or degeneration of additional internal organs typical of clinical disease caused by a viremia, as reported in experimental VHSV infections of juvenile herring (Kocan et al. 1997). In adult herring, clinical signs of lethargy and skin ulcers accompanied by renal tubular degeneration and/or necrosis and active RE cell foci in the liver and other major organs may be considered presumptive evidence for VHSV. In juvenile fish, systemic organ necrosis, including some form of hepatocellular necrosis, would also be required for a presumptive diagnosis. In both adult and juvenile herring, these lesions should be associated with cell culture isolations of VHSV at or above threshold tissue concentrations suggestive of clinical VHS disease. Definitive studies are needed to demonstrate virus particles, viral antigens, or nucleic acid in histological lesions suspected to be caused by VHSV.

\section{Oil and VHSV}

Finally, the answer to the question 'Does oil induce or exacerbate VHSV expression in herring?' appears to be 'not likely.' Although suggestive, the correlation of VHSV prevalence with oil exposure dose as evaluated in Carls et al. (1998) must be considered as unconfirmed data because the results could not be repeated by 3 other studies under controlled laboratory conditions.
Acknowledgements. R.A.E. and AquaTechnics staff acknowledge funding from ExxonMobil Corporation for their work on this review paper. K. Humphrey and P. Frelier are acknowledged for assistance in review and preparation of portions of the paper and $\mathrm{H}$. Elston for editing assistance. B. Barbo of Blue Heron Business Services is acknowledged for editing assistance. T.R.M. performed histological and virus cell culture work during the course of his regular duties as Principal Fish Pathologist for the Alaska Department of Fish and Game (ADFG), with partial funding from several Exxon Valdez Oil Spill Trustee Council restoration projects regarding the health and recovery of Pacific herring in PWS. The opinions expressed by the authors may not necessarily represent those of the ADFG, the Trustee Council, or ExxonMobil. The equation for estimating expected additive effects of OWD and VHSV was provided by J. Skalski, School of Aquatic and Fishery Sciences, University of Washington, Seattle. K. Parker performed correlation analyses reported in the paper. Both statisticians were supported by ExxonMobil Corporation for this work.

\section{LITERATURE CITED}

Ashe D, Gray D, Lewis B, Moffitt S, Merizon R (2005) Prince William Sound management area 2004 annual finfish management report. Fishery Management Report No. 0565. Alaska Department of Fish and Game, Division of Commercial Fisheries, Cordova, AK

Basurco B, Vende P, Monnier AF, Winton JR, de Kinkelin P, Benmansour A (1995) Genetic diversity and phylogenetic classification of viral hemorrhagic septicemia virus (VHSV). Vet Res 26:460-463

Batts WN, Arakawa CK, Bernard J, Winton JR (1993) Isolates of viral hemorrhagic septicemia virus from North America and Europe can be detected and distinguished by DNA probes. Dis Aquat Org 17:67-71

Brunson R, True K, Yancey J (1989) VHS virus isolated at Makah National Fish Hatchery. Am Fish Soc Fish Health Sect Newsl 17:3

Carls MG, Marty GD, Meyers TR, Thomas RE, Rice SD (1998) Expression of viral hemorrhagic septicemia virus in prespawning Pacific herring (Clupea pallasi) exposed to weathered crude oil. Can J Fish Aquat Sci 55:2300-2309

> Deriso RB, Maunder MN, Skalski JR (2007) Variance estimation in integrated assessment models and its importance for hypothesis testing. Can J Fish Aquat Sci 64:187-197

Drolet BS, Chiou PP, Heidel J, Leong JC (1995) Detection of truncated virus particles in a persistent RNA virus infection in vivo. J Virol 69:2140-2147

Eaton WD, Hulett J (1990) The fourth (and fifth?) isolation of viral hemorrhagic septicemia virus in Washington State. Am Fish Soc Fish Health Sect Newsl 18:3

> Einer-Jensen K, Ahrens P, Forsberg R, Lorenzen N (2004) Evolution of the fish rhabdovirus haemorrhagic septicemia virus. J Gen Virol 85:1167-1179

Elsayed E, Faisal M, Thomas M, Whelan G, Batts W, Winton J (2006) Isolation of viral hemorrhagic septicemia virus from muskellunge, Esox masquinongy (Mitchell), in Lake St. Clair, Michigan, USA reveals a new sublineage of the North American genotype. J Fish Dis 29:611-619

Elston RA, Drum AS, Pearson WH, Parker K (1997) Health and condition of Pacific herring Clupea pallasi from Prince William Sound, Alaska, 1994. Dis Aquat Org 31:109-126

Foy RJ, Norcross BL (2001) Temperature effects on zooplankton assemblages and juvenile herring feeding in Prince 
William Sound, Alaska. In: Funk F, Blackburn J, Hay D, Paul AJ, Stephenson R, Toresen R, Witherall D (eds) Herring: expectations for a new millennium. University of Alaska Sea Grant, AK-SG-01-04, Fairbanks, AK, p 21-35

> Gagne N, MacKinnon AM, Boston L, Souter B, Cook-Versloot M, Griffiths S, Olivier G (2007) Isolation of viral hemorrhagic septicemia virus from mummichog, stickleback, striped bass and brown trout in eastern Canada. J Fish Dis 30:213-223

Groocock GH, Getchell RG, Wooster GA, Britt KL and others (2007) Detection of viral hemorrhagic septicemia in round gobies in New York State (USA) waters of Lake Ontario and the St. Lawrence River. Dis Aquat Org 76:187-192

> Hedrick RP, Batts WN, Yun S, Traxler GS, Kaufman J, Winton JR (2003) Host and geographic range extensions of the North American strain of viral hemorrhagic septicemia virus. Dis Aquat Org 55:211-220

Hershberger PK, Kocan RM, Elder NE, Meyers TR, Winton JR (1999) Epizootiology of viral hemorrhagic septicemia virus in Pacific herring from the spawn-on-kelp fishery in Prince William Sound, Alaska, USA. Dis Aquat Org 37:23-31

Hershberger P, Hart A, Gregg J, Elder N, Winton J (2006) Dynamics of viral hemorrhagic septicemia, viral erythrocytic necrosis, and ichthyophoniasis in confined juvenile Pacific herring Clupea pallasii. Dis Aquat Org 70:201-208

Hershberger PK, Gregg J, Pacheco C, Winton J, Richard J, Traxler G (2007) Larval Pacific herring, Clupea pallasii (Valenciennes), are highly susceptible to viral haemorrhagic septicemia and survivors are partially protected after their metamorphosis to juveniles. J Fish Dis 30: $445-458$

Hopper K (1989) The isolation of VHSV from Chinook salmon at Glenwood Springs, Orcas Island, Washington. Am Fish Soc Fish Health Sect Newsl 17:1

Hulson PJF, Miller SE, Quinn TJ, Marty GD, Moffitt SD, Funk F (2008) Data conflicts in fishery models: incorporating hydroacoustic data into the Prince William Sound Pacific herring assessment model. ICES J Mar Sci 65:44-50

Jubb KVF, Kennedy PC, Palmer N (eds) (1993) Pathology of domestic animals, 4th edn. Academic Press, Orlando, FL

Kennedy CJ, Farrell AP, Sanders S (1999) Investigation of disease factors affecting declines of Pacific herring populations in Prince William Sound. Section III. Survival, performance and reproduction in the Pacific herring, Clupea harengus pallasi: effects of environmental contamination, viral hemorrhagic septicemia virus and Ichthyophonus hoferi. Final Report (Restoration Projects 95320, 96162, 97162, 98162), Simon Fraser University, Burnaby, British Columbia

Kent ML, Traxler GS, Kieser D, Richard J and others (1998) Survey of salmonid pathogens in ocean-caught fishes in British Columbia, Canada. J Aquat Anim Health 10: 211-219

Kocan RM (1994) United States District Court for the District of Alaska, Case No. A89-0095 CIV (HRH) The Exxon Valdez. Testimony, 23 June 1994, Transcript of Proceedings, Trial by Jury, 32nd day, Anchorage, Alaska, Vol 27, p 4717-4913

Kocan RM, Marty GD, Okihiro MS, Brown ED, Baker TT (1996) Reproductive success and histopathology of individual Prince William Sound Pacific herring 3 years after the Exxon Valdez oil spill. Can J Fish Aquat Sci 53: 2388-2393

Kocan RM, Bradley M, Elder NE, Meyers TR, Batts W, Winton JR (1997) North American strain of viral hemorrhagic septicemia virus is highly pathogenic to laboratory-reared Pacific herring. J Aquat Anim Health 9:279-290
Kocan RM, Hershberger PK, Elder NE, Winton JR (1999) Controlled field and laboratory studies on viral hemorrhagic septicemia (VHS) and Ichthyophonus in Pacific herring. Section II. In: Investigations of disease factors affecting declines of Pacific herring populations in Prince William Sound. Exxon Valdez oil spill restoration project annual report, Restoration Project 98162, Alaska Department of Fish and Game, Anchorage, AK

> Kocan RM, Hershberger PK, Elder NE, Winton JR (2001) Epidemiology of viral hemorrhagic septicemia among juvenile Pacific herring and Pacific sand lances in Puget Sound, Washington. J Aquat Anim Health 13:77-85

> Kocan RM, LaPatra S, Gregg J, Winton J, Hershberger P (2006) Ichthyophonus-induced damage: a mechanism for reduced swimming stamina in salmonids. J Fish Dis 29: $521-527$

López-Vázquez C, Raynard RS, Bain N, Snow M, Bandín I, Dopazo CP (2006) Genotyping of marine viral haemorrhagic septicaemia virus isolated from the Flemish Cap by nucleotide sequence analysis and restriction fragment length polymorphism patterns. Dis Aquat Org 73:23-31

Lumsden JS, Morrison B, Yason C, Russell S and others (2007) Mortality event in freshwater drum Aplodinotus grunniens from Lake Ontario, Canada, associated with viral hemorrhagic septicemia virus, Type IV. Dis Aquat Org 76: 99-111

MacLean SA (2006) Salmonid pathogens in northwestern Atlantic fishes. Working paper no. 2006/01. US Atlantic Salmon Assessment Committee Meeting Report, NOAA, Gloucester, MA

> Marty GD, Freiberg EF, Meyers TR, Wilcock J, Farver TB, Hinton DE (1998) Viral hemorrhagic septicemia virus, Ichthyophonus hoferi, and other causes of morbidity in Pacific herring Clupea pallasi spawning in Prince William Sound, Alaska, USA. Dis Aquat Org 32:15-40

> Marty GD, Okihiro MS, Brown ED, Hanes D, Hinton DE (1999) Histopathology of adult Pacific herring in Prince William Sound, Alaska, after the Exxon Valdez oil spill. Can J Fish Aquat Sci 56:419-426

Marty GD, Quinn TJ II, Carpenter G, Meyers TR, Willits NH (2003) Role of disease in abundance of a Pacific herring (Clupea pallasi) population. Can J Fish Aquat Sci 60: 1258-1265

Marty GD, Quinn TJ, Miller SE, Meyers TR, Moffitt SD (2004) Effect of disease on recovery of Pacific herring in Prince William Sound, Alaska. Restoration project no. 030462, Final Report. EVOS Trustee Council, Anchorage, AK

McAllister PE, Batts WN (1994) Viral hemorrhagic septicemia. In: JC Thoesen (ed) Suggested procedures for the detection and identification of certain finfish and shellfish pathogens. Fish Health Blue Book. American Fisheries Society, Bethesda, MD

> Meyers TR (1980) Experimental pathogenicity of reovirus 13 $3_{\mathrm{P} 2}$ for juvenile American oysters Crassostrea virginica (Gmelin) and bluegill fingerlings Lepomis macrochirus (Rafinesque). J Fish Dis 3:187-201

> Meyers TR (1983) Serological and histopathological responses of rainbow trout, Salmo gairdneri Richardson, to experimental infection with the $13_{\mathrm{P} 2}$ reovirus. J Fish Dis 6: $277-292$

> Meyers TR (1998) Healthy juvenile sockeye salmon reared in virus-free hatchery water return as adults infected with IHNV: a case report and review of controversial issues in the epizootiology of IHNV. J Aquat Anim Health 10: 172-181

> Meyers TR, Winton JR (1995) Viral hemorrhagic septicemia virus in North America. Annu Rev Fish Dis 5:3-24 
Meyers TR, Sullivan J, Emmenegger E, Follett J, Short S, Batts WN, Winton JR (1992) Identification of viral hemorrhagic septicemia virus isolated from Pacific cod Gadus macrocephalus in Prince William Sound, Alaska, USA. Dis Aquat Org 12:167-175

Meyers TR, Short S, Lipson K, Batts WN, Winton JR, Wilcock J, Brown E (1994) Association of viral hemorrhagic septicemia virus with epizootic hemorrhages of the skin in Pacific herring Clupea harengus pallasi from Prince William Sound and Kodiak Island, Alaska, USA. Dis Aquat Org 19:27-37

Meyers TR, Short S, Lipson K (1999) Isolation of the North American strain of viral hemorrhagic septicemia virus (VHSV) associated with epizootic mortality in two new host species of Alaskan marine fish. Dis Aquat Org 38: $81-86$

Moffitt S (2006) ADF\&G age-structured assessment model and data for Prince William Sound herring. Alaska Department of Fish and Game, Division of Commercial Fisheries, Cordova, AK

Moles AD, Rice SD, Okihiro MS (1993) Herring parasites and tissue alterations following the Exxon Valdez oil spill. Proceedings of the 1993 Oil Spill Conference, API Publ. No. 4580, American Petroleum Institute, Washington, DC, p 325-328

Pearson WH (2005) PAHs and other contaminants in effluents from artificially weathered oil on gravel. Document API 14718A-IOSC 2005, available on CD-ROM: IOSC 2005 a158, 4 p, 2005 International Oil Spill Conference. American Petroleum Institute, Washington, DC

Pearson WH, Woodruff DL, Kiesser SL, Fellingham GW, Elston RA (1985) Oil effects on spawning behavior and reproduction in Pacific herring (Clupea harengus pallasi). API Publication No. 4412. Health and Environmental Sciences Department, American Petroleum Institute, Washington, DC

Pearson WH, Elston RA, Bienert RW, Drum AS, Antrim LD (1999) Why did the Prince William Sound, Alaska Pacific herring (Clupea pallasi) fisheries collapse in 1993 and 1994? Review of hypotheses. Can J Fish Aquat Sci 56: 711-737

Quinn TJ II, Marty G, Wilcock J, Willette M (2001) Disease and population assessment of Pacific herring in Prince William Sound, Alaska. In: Funk F, Blackburn J, Hay D, Paul AJ, Stephenson R, Toresen R, Witherell D (eds) Herring: expectations for a new millennium. University of Alaska Sea Grant, AK-SG-01-04, Fairbanks, AK, p 363-379

Sanders SM (2005) Immunotoxicology of Pacific herring: determination of reference ranges and their application to assessing exposure to the water-soluble fraction of crude oil. PhD dissertation, Simon Fraser University, Burnaby, British Columbia

Short JW, Harris PM (1996) Chemical sampling and analysis of petroleum hydrocarbons in near-surface seawater of

Editorial responsibility: Mark Crane, Geelong, Victoria, Australia
Prince William Sound after the Exxon Valdez oil spill. Am Fish Soc Symp 18:17-28

Skall HF, Olesen NJ, Mellergaard S (2005) Viral hemorrhagic septicemia virus in marine fish and its implications for fish farming: a review. J Fish Dis 28:509-529

Skalski JR, Ryding KE, Millspaugh JJ (2005) Wildlife demography: analysis of sex, age, and count data. Academic Press, San Diego, CA

Snow M, Cunningham CO, Melvin WT, Kurath G (1999) Analysis of the nucleoprotein gene identifies distinct lineages of viral hemorrhagic septicemia virus within the European marine environment. Virus Res 63:35-44

Stewart BB, Olson C, Lutz S (1990) VHS virus detected at Lummi Bay Sea Ponds, Bellingham, Washington. Am Fish Soc Fish Health Sect Newsl 18:2

Tester AL (1942) Herring mortality along the southeast coast of Vancouver Island. Fish Res Board Can Prog Rep Pac Coast Stn 52:11-15

Thomas RE, Carls MG, Rice SD, Shagrun L (1997) Mixed function oxygenase induction in pre- and post-spawn herring (Clupea pallasi) by petroleum hydrocarbons. Comp Biochem Physiol 116C:141-147

Thorne RE, Thomas GL (2008) Herring and the 'Exxon Valdez' oil spill: an investigation into historical data conflicts. ICES J Mar Sci 65:44-50

Traxler GS, Kieser D (1994) Isolation of the North American strain of viral hemorrhagic septicemia virus (VHSV) from herring (Clupea harengus pallasi) in British Columbia. Am Fish Soc Fish Health Sect Newsl 22:8

Traxler GS, Kieser D, Evelyn TPT (1995) Isolation of North American strain of VHS virus from farmed Atlantic salmon. Aquaculture Update 72:1-2

Traxler GS, Kieser D, Richard J (1999) Mass mortality of pilchard and herring associated with viral hemorrhagic septicemia virus in British Columbia, Canada. Am Fish Soc Fish Health Sect Newsl 27:3-4

Venables WN, Ripley BD (1997) Modern applied statistics with S-Plus, 2nd edn. Springer, New York

- Winters GH, Wheeler JP (1994) Length-specific weight as a measure of growth success of adult Atlantic herring ( $\mathrm{Clu}$ pea harengus). Can J Fish Aquat Sci 51:1169-1179

Winton JR, Batts WN, Deering R, Brunson R, Hopper $K$, Nishizawa T, Stehr C (1991) Characterization of the first North American isolates of viral hemorrhagic septicemia virus. Proc Second International Symposium on Viruses of Lower Invertebrates. Oregon State University, Corvallis, OR, p 43-50

Winton J, Batts B, Kurath G (2007) Detection of viral hemorrhagic septicemia virus. USGS FS 2007-3055, available at www.nwhc.usgs.gov/disease_information/other_diseases/ VHS-7-12-2007.pdf

Winton J, Batts B, Kurath G (2008) Molecular epidemiology of viral hemorrhagic septicemia virus in the Great Lakes region. USGS FS 2008-3003, available at http://wfrc.usgs. gov/pubs/factsheetpdf/vhsfs2011108.pdf

Submitted: August 29, 2007; Accepted: October 31, 2008

Proofs received from author(s): February 10, 2009 